WHC-SA- $-1392-$ Rev . I

DE92 008367

Comparison of

Fracture Behavior for

Low-Swelling Ferritic

and Austenitic Alloys

Irradiated in the Fast

Flux Test Facility

(FFTF) to 180 DPA

F. H. Huang

Date Published

February 1992

To Be Published in

Engineering Fracture Mechanics

Prepared for the U.S. Department of Energy

Assistant Secretary for Nuclear Energy

$\begin{array}{ll}\text { Westinghouse } & \text { P.O. Box } 1970 \\ \text { Hanford Company } & \text { Richland, Washington } 99352\end{array}$

Hanford Operations and Engineenng Contractor for the

U.S. Department of Energy under Contract DE-AC06-87RL10930

Copyright License By acceptance of thus artele. the publisher andior reciplent acknowledges the U.S Government s right to

tetain a nonexclusive, royalty-tree license in and to any copyright covering this paper.

Approved for Public Release 


\section{DISCLAIMER}

Portions of this document may be illegible in electronic image products. Images are produced from the best available original document. 


\section{LEGAL DISCLAIMER}

This report was prepared as an account of work sponsored by an agency of the United States Government. Neither the

United States Government nor any agency thereof, nor any of their employees, nor any of their contractors, subcontractors or their employees, makes any warranty, express or implied, or assumes any legal liability or responsibility for the accuracy. completeness, or any third party's use or the results of such use of any information, apparatus, product, or process disclosed, or represents that its use would not iniringe privately owned rights. Reierence herein to any spectic commercial product, process, or service by trade name, trademark, manulacturer, or otherwise, does not necessarlly constitute or imply its endorsement, recommendation, or favoring by the United States Government or any agency thereof or its coniractors or subcontractors. The views and opinions of authors expressed herein do not necessarily state or reflect those of the United Slates Government or any agency thereoi.

This report has been reproduced from the best available copy.

Pzinted in the United States of Amotica

OISCLM-2.CHP (1-91) 
WHC-SA-1392-FP

Rev. 1

\title{
COMPARISON OF FRACTURE BEHAVIOR FOR LOW-SWELLING FERRITIC AND AUSTENITIC ALLOYS IRRADIATED IN THE FAST FLUX TEST FACILITY (FFTF) TO 180 DPA
}

\author{
F. H. Huang \\ Westinghouse Hanford Company, Richland, WA 99352, U.S.A.
}

\begin{abstract}
Fracture toughness testing was conducted to investigate the radiation embrittlement of high-nickel superalloys, modified austenitic steels and ferritic steels. These materials have been experimentally proven to possess excellent resistance to void swelling after high neutron exposures. In addition to swelling resistance, post-irradiation fracture resistance is another important criterion for reactor material selection. By means of fracture mechanics techniques the fracture behavior of those highly irradiated alloys was characterized in terms of irradiation and test conditions. Precipitation-strengthened alloys failed by channel fracture with very low postirradiation ductility. The fracture toughness of titanium-modified austenitic stainless steel D9 deteriorates with increasing fluence to about 100 displacement per atom (dpa), the fluence level at which brittle fracture appears to occur. Ferritic steels such as HTg are the most promising candidate materials for fast and fusion reactor applications. The upper-shelf fracture toughness of alloy HTg remained adequate after irradiation to 180 dpa although its ductile-brittle transition temperature (DBTT) shift by low temperature irradiation rendered the material susceptible to brittle fracture at room temperature. Understanding the fracture characteristics under various irradiation and test conditions helps reduce the potential for brittle fracture by permitting appropriate measures to be taken.
\end{abstract}


WHC-SA-1392-FP

Rev. 1

\section{INTRODUCTION}

The mechanical properties of core components in advanced reactors will be degraded by large fluxes of fast neutron and energetic charged particles; it is therefore of vital interest to search continuousiy for improved alloys for these components and test them in hostile environments. Neutron bombardment of the materials causes swelling, creep and embrittlement problems. Void swelling and irradiation creep lead to the dilation and bowing of reactor core components and limit the achievable burn-ups in the fuel. These dimensional instability may create overstress or overheating, indirectly resulting in failure.

of great concern is the radiation embrittlement caused by high neutron exposure. The lifetime of the core components depends mostly on the degree of embrittlement they suffered. Emphasis has been placed on swelling reduction improvements since austenitic steels first used in fast reactors applications were found to swell 30 percent at $400{ }^{\circ} \mathrm{C}$. Subsequent reactor experiments have shown that high nickel superalloys [1], titanium (Ti)-modified austenitic steels [2] and ferritic/martensitic steels [3] all exhibit less than 1 percent increase in volume after high fluence irradiation. As the dose has recently accumulated up to $230 \mathrm{dpa}$ in the Fast Flux Test Facility (FFTF) in Richland, Washington, it is important to investigate the extent of radiation embrittlement for these materials. Tensile testing, though simple and economical, is not a reliable method for radiation embrittlement studies because the flawed structures may fail catastrophically at a stress level much lower than the yield stress, and the ductility becomes less sensitive to a change in irradiation conditions in high fluence environments. 
The need to assess radiation-induced toughness degradation is met best by fracture mechanics techniques. The efforts of those involved in developing fracture mechanics techniques have made available reasonably accurate fracture test methods. Linear elastic fracture mechanics (LEFM) has been employed to evaluate the severity of a crack in a structure. In the case where the structure does not exhibit linear elastic behavior, the large plastic strain developed around the crack tip prevents LEFM from being applied. A plasticity correction term is then introduced, and elastic-plastic fracture mechanics (EPFM) is used to characterize the ductile fracture behavior.

EPFM techniques were used to evaluate the fracture toughness of reactor materials and subsized compact tension specimens were preferred, as reactor core components were thin (on the order of a few millimeters) and usually fail by ductile fracture. Irradiation space saving and temperature gradient reduction are other reasons for using small specimens. However, reducing specimen size for irradiated materials without jeopardizing data validity is not straightforward. The effect of specimen size on fracture toughness has been investigated [4]. To perform the irradiation experiments, test specimens were prepared from material stocks of interest and placed in the FFTF for irradiation or cut from reactor components with desired irradiation conditions. Test results obtained from various highly irradiated alloys exhibiting superior swelling resistance were analyzed by means of fracture mechanics techniques. Suggestions will be made about which material is suitable for use in high neutron fluence environments and worth further efforts. 
WHC-SA-1392-FP

Rev. 1

\section{EXPERIMENTAL PROCEDURE}

\section{Specimen Preparation}

Compact tension specimens were prepared from alloys 066 (high-nickel superalloy), D9 (Ti-modified austenitic steel) and HT9 (ferritic/martensitic steel). Table 1 lists the chemical compositions of these alloys. Two types of compact tension specimen were tested in this work: a disk-shaped and a rectangular specimen. The $2.54-\mathrm{mm}$ thick and $16-\mathrm{mm}$ diameter disk-shaped specimens were machined from 2.8-mm-thick rolled stock of D66 and D9, and from 3.2-mm-thick stock formed from $33.3 \mathrm{~mm}$ diameter bar stock of HT9 (heat No.91353 and 84425$)$. The final heat treatment for HTg was $1038{ }^{\circ} \mathrm{C} / 5 \mathrm{~min} / \mathrm{AC}+$ $760^{\circ} \mathrm{C} / 30 \mathrm{~min} / \mathrm{AC}$.

The D66 specimens were irradiated in the Experimental Breeder Reactor-II (EBR) to a fluence of $2.7 \times 10^{22} \mathrm{n} / \mathrm{cm}^{2}$ and $H T g$ specimens in the FFTF to a fluence of $38.5 \times 10^{22} \mathrm{n} / \mathrm{cm}^{2}$ (equivalent to about $180 \mathrm{dpa}$ for HT9). The preirradiation toughness and crack propagation resistance were so low that none of the irradiated 066 specimens was tested.

Compact tension specimens were al so cut from a $3-\mathrm{mm}$ thick FFTF duct of 09 which had been irradiated to a peak fluence of $23.5 \times 10^{22}$ ( $E>0.1 \mathrm{MeV}$ ). The duct was fabricated by Clark and wheeler from heat no. N562. The specimen had a width of $12.7 \mathrm{~mm}$; the dimensions of compact tension specimen are in Ref. 5. Alloy D9 is a Ti-modified AISI 316 stainless steel (316 SS) and swells only a little compared to 316 SS. All specimens of D66, D9 and HT9 were tested by means of the single-specimen electric-potential method. Four steel electrodes were welded to each specimen to make the connection of electrical leads in the hot cell easier. 
WHC-SA-1392-FP

Rev. 1

\section{Test Procedure}

The test procedure was not much different from that reported earlier [5]. Postirradiation $\mathrm{K}_{\mathrm{Ic}}$ and $\mathrm{J}_{\mathrm{Ic}}$ fracture toughness tests were performed at 30, 205, and $410{ }^{\circ} \mathrm{C}$ in accordance with the test procedures outlined in ASTM E339 and E813, respectively. Before testing, each specimen was fatigue precracked to an $a / w$ ratio of approximately 0.55 by the electric potential technique to monitor the crack length. To insulate the test specimen assembly electrically, ceramic spacers were placed in the couplings of the pull rods. During each test, the load, electric potential output, and displacement were recorded continuously. After the test was completed, each cracked specimen was heat tinted at $400{ }^{\circ} \mathrm{C}$ to reveal the crack extension.

The specimen used in irradiated testing was more than one hundred times smaller than the one recommended in the ASTM standards, but three types of fracture behavior were observed to result from fracture degradation following irradiation: (1) unstable fracture -- the loading curve was a straight line up to the maximum load and the electric potential increased suddenly at the maximum load as shown in Figure 1; (2) stable tearing followed by unstable fracture -- the loading curve displayed some plastic deformation up to the maximum load followed by the rapid decline of the load while the electricpotential increased drastically before reaching the maximum load as shown in Figure 2; (3) stable tearing -- both load and potential output increased smoothly up to the maximum load; the load then decreased gradually while the potential output continued to increase as shown in Figure 3. 
WHC-SA-1392-FP

Rev. 1

\section{Fractography}

Fractographic examination was performed using a scanning electron microscope (Model JSM-35C) operating at $25 \mathrm{keV}$. To minimize personnel radiation exposure, a sliver of material containing the fracture surfaces was sectioned from tested samples using an acid saw.

\section{RESULTS}

\section{A110y 066}

Load and potential output versus displacement curves of unirradiated D66 are shown in Figure 4. The electric potential curve deviated abruptly in the region of crack initiation and then extended upward smoothiy. The values of $J_{l c}$ were obtained from 066 specimens tested at 25 and $232{ }^{\circ} \mathrm{C}$. Type 2 fracture behavior was obtained for 066 samples that were not exposed to neutron irradiation. The low values of fracture toughness and tearing modulus listed in Table 2 and plotted in Figures 5 and 6 indicate that D6 6 has weak fracture resistance. This characteristic was consistent with fractography that showed D66 fractured by flow localization with channel facets on the fracture surface. More on this subject will be discussed later.

\section{Alloy Dg}

Two high fluence samples cut from the Dg duct failed during fatigue precracking at stress intensity levels of about 12-14 MPa/m. The third one, tested without precracking, failed by unstable brittle fracture without plastic deformation (Figure 1). The fracture toughness of this unprecracked specimen was over-estimated because the notch tip in the specimen was blunt. 
The specimens cut from the lower fluence $\left(9-10 \times 10^{22} \mathrm{n} / \mathrm{cm}^{2}\right)$ section of the $D 9$ duct exhibited stable tearing. The equivalent $K_{1 c}$ computed from $J_{1 c}$, termed as $K_{c}$, are given in Table 2. For $D 9$ specimens irradiated to a fluence of $10 \times 10^{22} \mathrm{n} / \mathrm{cm}^{2}$ and tested at $410{ }^{\circ} \mathrm{C}$, Type 2 fracture behavior was observed (Figure 3 ). Results are plotted in Figure 7 as a function of test temperature; also plotted in the figure are fracture toughness data for 316 SS irradiated to a fluence of $16 \times 10^{22} \mathrm{n} / \mathrm{cm}^{2}$. Evidently, the postirradiation toughness of D9 decreased slightly with increasing test temperature and was inferior to that of 316 SS.

The values of the tearing modulus for 09 samples are also given in Table 2 and plotted in Figure 6 , which shows that the crack propagation resistance in 09 was reduced significantly after irradiation.

\section{Alloy HTg}

A11 HTg samples tested displayed stable tearing. Load and potential output curves for HTg irradiated to a fluence as high as $38.5 \times 10^{22} \mathrm{n} / \mathrm{cm}^{2}$ are shown in Figure 8. The values of $K_{c}$ and $T$ are listed in Table 2 and plotted in Figures 9 and 10 . Results showed that the fracture toughness value of HTg irradiated to a high fluence of $38.5 \times 10^{22} \mathrm{n} / \mathrm{cm}^{2}$ was greater than $100 \mathrm{MP}$ avm. For HTg irradiated to a fluence of $14 \times 10^{22} \mathrm{n} / \mathrm{cm}^{2}$ at $550^{\circ} \mathrm{C}$, the toughness (122 MPa $\sqrt{ }$ ) was slightly larger than that of HTg samples cut from the FFTF duct that was irradiated to $16 \times 10^{22} \mathrm{n} / \mathrm{cm}^{2}$ at $411^{\circ}$ [5]. Overall, the present data proved that the fracture toughness of HTg remained adequate when the material was irradiated at temperatures at $400{ }^{\circ} \mathrm{C}$ or higher. 
Rev. 1

\section{DISCUSSION}

\section{Fracture Mechanism}

\section{A1 loy D66}

In nickel and its solid-solution alloys, ductility troughs were observed decades ago in the neighborhood of $600{ }^{\circ} \mathrm{C}[6]$. The fracture mode changes from a low-temperature ductile fracture to a high-temperature brittle intergranular fracture as the temperature increases from approximately half the absolute melting temperature. It changes because at high temperature, cavities are nucleated and grow as grain boundaries slide significantly. High-temperature intergranular embrittlement also results from the grain boundary segregation because the presence of impurities on the grain boundaries reduces the energy absorption in fracture.

The extremely low ductilities of the precipitation-strengthened alloys after irradiation are believed to be caused by the precipitation of $\gamma^{\prime}$ ( $\mathrm{Ni}_{3} \mathrm{Si}$ or $\left.\mathrm{Ni}_{3} \mathrm{~A}\right]$ ) near or along the grain boundaries [7]. The $\gamma^{\prime}$ precipitates developed during the double-aged treatment for 066 contribute the high strength of the alloy but also induce slip in confined regions, or channels, during deformation. Alloy 066 was fractured by flow localization as indicated by the presence of channel facets on the fracture surface (Figure-11). This type of failure is analogous to the channel fracture of irradiated stainless steels first observed by Fish et al. [8].

\section{Alloy D9}

The scanning electron microscope (SEM) fractographs for unirradiated and irradiated 20 percent CW 316 SS were compared in Ref. 9. After irradiation the facets generated by a shear process on the fracture surfaces of 20 percent 
cold worked (CW) 316 SS replaced the transgranular plastic dimpling feature. The fracture surface morphologies of $D 9$ are believed to be little different from 20 percent $\mathrm{CW} 316$ SS. Large amounts of channel fracture are expected in D9 duct samples irradiated to $22 \times 10^{22} \mathrm{n} / \mathrm{cm}^{2}$. Irradiation causes dislocation channeling, which creates defect-free channels resulting in channel fracture morphology [8]. Irradiation at 400 to $482{ }^{\circ} \mathrm{C}$ in alloy 09 produces $\gamma^{\prime}\left(\mathrm{Ni}_{3} \mathrm{Si}\right)$ and $\eta(\mathrm{Cr}-\mathrm{Ni}-\mathrm{Silicide})$. These phases become obstacles to the movement of dislocation; a larger force therefore is required for dislocation to pass through these phases, and this process results in an increase in yield stress for irradiated D9. Voids and Frank loops also contribute to the yield stress increase. A high yield strength alloy like irradiated $D 9$ tends to exhibit poor toughness because the resistance to slip is so high that the fracture stress is reached before plastic deformation can occur.

\section{Alloy HTg}

The fracture process observed in HTg irradiated to a fluence of $5.5 \times 10^{22} \mathrm{n} / \mathrm{cm}^{2}$ changed little with fluence [10]. As shown in Figure 12a, the fracture surfaces of highly irradiated HT9 were characterized by ductile dimpling through microvoid coalescence. These fracture surfaces are in contrast to the plate-like faceted fracture surfaces of high-nickel superalloys or irradiated austenitic steels. However, stable tearing would change to cleavage fracture behavior if the HTg were irradiated at $360^{\circ} \mathrm{C}$ and tested at room temperature (Figure 12b). The flatness of the facets and irregular cleavage steps with river patterns are visible in this figure. These are evident fractographic features for cleavage fracture. Fine scale precipitates such as G-phase, a face-centered cubic (fcc) nickel silicide, and 
dislocation loops formed during irradiation at low temperatures are believed to cause a large amount hardening. The critical stress for cleavage fracture can be reached at a higher temperature, thus raising the ductile-brittie transition temperature (DBTT) [11].

In body-centered cubic (bcc) structures such as HT9 there exists a large energy barrier in lattice to dislocation slip; the materials are likely to fail through low-index crystallographic planes without significant plastic deformation. Both cleavage and channel fracture are the worst cases of fracture and always catch the engineer by surprise. While scientists are still unable to prevent channel fracture from occurring in austenitic alloys, the cleavage fracture can be avoided simply by increasing irradiation or handling temperature [5]. Figures $12 \mathrm{a}$ and $12 \mathrm{~b}$ show that the fracture feature was altered from dimpling rupture at $205{ }^{\circ} \mathrm{C}$ to cleavage facet at room temperature for FFTF duct samples irradiated at $360^{\circ} \mathrm{C}$. High temperature softens the hardening in ferritic steels resulting from irradiation, and reduces the shear strength, which becomes smaller than the cohesive strength; thus the crack will blunt plastically before it can initiate and propagate.

\section{Subsized Specimen for Postirradiation Testing}

For reasons mentioned in the previous sections, small specimens have more advantages over large specimens for postirradiation fracture testing with electric potential techniques. The electric potential techniques are capable of revealing the rapid crack initiation and propagation for the second type of fracture behavior, stable tearing followed by unstable fracture. Experimental evidence has shown that reasonably accurate plane strain fracture toughness can be obtained from specimens of various sizes if the specimen size criteria 
recommended in ASTM E399 are satisfied. In the present study, highly irradiated D9 samples with a thickness of $2.54 \mathrm{~mm}$ and the $K_{1 c}$ values of about $22 \mathrm{MPa}$ am or lower should satisfy the thickness criterion: $2.5\left(\mathrm{~K}_{a} / \sigma_{y}\right)^{2}$. As the specimens exhibited linear elastic behavior, the other requirements for valid data should also be met.

Requirements for the validity of fracture toughness data obtained from specimens exhibiting stable tearing are more complicated because stable tearing depends on a "data exclusion zone" (DEZ) size for $J_{1 c}$ determination. While initiation fracture toughness is not specimen-size dependent, in maintaining J-controlled conditions the DEZ size is. The minimum thickness $\left(25 J_{I c} / \sigma_{y}\right)$ required for valid $J_{1 c}$ values is satisfied by the $1.02-m m-t h i c k$ specimens of 20 percent CW 316 SS and the 2.54-mm-thick specimens of D9, as a result of low toughness and irradiation hardening. To compare the fracture responses of different materials to irradiation, the procedure for $J_{1 c}$ determination needs to be consistent for all subsized samples of various materials.

\section{Irradiated Effect On Fracture Resistance}

The iron-nickel base precipitation-strengthened alloys have been long noted for their superior high-temperature strength and resistance to radiation-induced void swelling. The development of the family of these alloys for use in fast reactors was an important part of the National Cladding/Duct Materials Development Program beginning in 1974 [12]. However, it soon was found that the commercial alloy Nimonic PEI6 exhibited zero ductility after neutron irradiation [13]. A great number of superalioy specimens in the shape of miniaturized transmission electron microscope (TEM) 
disks with different composition and thermomechanical treatments (TMT), irradiated to fluences of 4.7 to $7.6 \times 10^{22} \mathrm{n} / \mathrm{cm}^{2}$, were available for mechanical property testing. Therefore, a quick screening test capable of measuring the ductility or toughness of these irradiated disk specimens was urgently needed. In 1978, a bend-test technique was developed at Westinghouse Hanford Company to permit rapid screening of irradiated disk specimens. The results had not been released by the time the test technique was reported in the open literature [14] in 1982. Table 3 lists some of those results for TEM disk specimens of six commercial and four developmental superalloys, along with the composition, irradiation and test conditions. The severe radiation embrittlement exhibited by specimens of all commercial as well as developmental alloys dashed the hope that the problems might be improved by varying composition and TMT.

Fracture toughness testing was performed on unirradiated superalloys 066 and D21 and on irradiated D21. A1though D21 has the best toughness compared to other superalloys, it exhibited stable tearing/unstable fracture behavior and poor crack propagation resistance [15]. The low fracture toughness resulting from channel fracture and high-temperature intergranular fracture is the common feature for all high-strength precipitation-strengthened alloys. These phenomena also occur in highly irradiated austenitic stainless steels.

The effects of irradiation on the fracture toughness of 20 percent cold-worked 316 SS were reported in References 9 and 16. The radiation embrittlement problems found in $316 \mathrm{SS}$ are expected to occur in alloy D9. In comparison, the toughness at the maximum load of irradiated $D 9^{2}$ was lower than that of irradiated 316 SS at temperatures above $200{ }^{\circ} \mathrm{C}$. Channel fracture features were also observed in $D 9$ under high neutron fluence. On the basis of 
these results, it is not certain whether the lowest fluence that causes channel fracture in alloy $D 9$ will be higher than that which causes the similar embrittlement in 316 SS, as previously was thought. The fracture toughness values of both alloys are plotted as a function of fluence in Figure 13. The figure shows that the fracture toughness degraded with fluence and that 09 may fail by brittle fracture at fluences near $20 \times 10^{22} \mathrm{n} / \mathrm{cm}^{2}$. Charpy test results show a correlation between swelling and embrittlement in cold worked Ti-modified 316 SS [17]. D9 exhibits lower swelling at fluences about 15 to $20 \times 10^{22} \mathrm{n} / \mathrm{cm}^{2}$. Thus, 09 may have better resistance to radiation embrittlement than 316 SS, based on Charpy tests.

Unlike austenitic steels, ferritic steels not only can suppress void swelling but also remain tough under high neutron fluence. Figure 14 shows the $410^{\circ} \mathrm{C}$ fracture toughness in terms of fluence; also plotted in the figure is the toughness data for D9. The fracture toughness of HT9 seemed to saturate with fluence, while D9 exhibited toughness that declined rapidly as the fluence was increased and failed by brittle fracture at fluences above 20 $\times 10^{22} \mathrm{n} / \mathrm{cm}^{2}$. At fluences about 10 to $12 \times 10^{22} \mathrm{n} / \mathrm{cm}^{2}$, once the crack in $D 9$ initiated, fast fracture followed; and the crack propagation resistance was very low, as indicated by the tearing modulus in Figure 15. The fracture mode in D9 changed from Type 3 (stable tearing) to Type 2 (stable tearing-unstable fracture) and ended as Type 1 (unstable fracture) as the fluence increased. In contrast to alloy D9, HT9 displayed a Type 3 fracture mode that was not altered by irradiation. The tearing modulus decreased with increasing fluence, but remained high even at fluences above $30 \times 10^{22} \mathrm{n} / \mathrm{cm}^{2}$. 
The results showing that HTg had a high fracture resistance to irradiation were somewhat surprising, as the material had been known to be susceptible to a ductile-brittle transition at a temperature (DBTT) that shifted upward with irradiation. The DBTT shift apparently was not changed significantly by neutron fluence. However, fracture toughness testing on a section of an FFTF duct from below a fuel column [5] revealed that HT9 irradiated at $360^{\circ} \mathrm{C}$ exhibited low fracture toughness and failed by brittle fracture at room temperature. The effects of irradiation on the mechanical properties of specimens from the center region of the FFTF duct (irradiation temperature $=419-445^{\circ} \mathrm{C}$ ) and the lower region (irradiation temperature $=$ $360^{\circ} \mathrm{C}$ ) are quite different. Apparently, irradiation temperature is the key factor in the degree of radiation embrittlement for ferritic steels. The important findings from these studies were the following: (a) the lowtemperature irradiated fracture samples of HTg failed without plastic deformation despite the fact that the tensile specimens of the same conditions exhibited 10 percent elongation. This finding indicated that fracture toughness testing is necessary to detect the potential for brittle fracture; (b) Increasing test temperature may increase the fracture toughness of the low-temperature irradiated HTg with fracture mode changing from cleavage to dimpling. This finding suggested that the brittle problems of ferritic steels may be alleviated by raising the handling or irradiation temperatures cautiously. For austenitic steels, the embrittlement concerns of channel fracture will not likely diminish. 


\section{Fast And Fusion Reactor Applications}

The swelling problem for austenitic stainless steels was reduced by varying the composition of the material, but the radiation-induced embrittlement remained a major problem for the high-exposure performance of austenitic steels in advanced reactors. Moreover, although Dg exhibits excellent swelling resistance at fluences around $10 \times 10^{22} \mathrm{n} / \mathrm{cm}^{2}$, it loses its superiority in suppressing swelling to 316 SS as the fluence increases to $36.9 \times 10^{22} \mathrm{n} / \mathrm{cm}^{2}$ (Table 4). Clearly, the use of alloy 09 should be limited to around $20 \times 10^{22} \mathrm{n} / \mathrm{cm}^{2}$; caution therefore should be taken in dealing with the potential risk of sudden failure for D9 components exposed to beyond this fluence range.

In addition to the superior fracture toughness under large neutron fluence, HTg was found to swell only 0.3 percent at a fluence as high as $32.9 \times 10^{22} \mathrm{n} / \mathrm{cm}^{2}$ (about $160 \mathrm{dpa}$ ) compared to 30 percent for Dg which has good swelling resistance at much lower fluences (see Table 4). This high resistance to radiation-induced swelling is inherent in ferritic steels (bcc alloys) and is explained as the consequence of the trapping of radiationinduced point defects by interstitial and substitutional solutes [18]. The significant effects of trapping on precipitation result in the phase stability in bcc materials under high neutron fluences [19].

Because the poor-toughness superalloys were not considered and the use of Ti-modified austenitic steels may have to be limited to about $100 \mathrm{dpa}$, ferritic steels emerge as the most promising candidate materials for fast and fusion reactor applications, especially for the fusion first wall, which has to withstand $40 \mathrm{MW}-\mathrm{y} / \mathrm{m}^{2}$ neutron irradiation (a displacement damage of approximately $480 \mathrm{dpa}$ for ferritic steels). Experimental results in this work 
have shown that no material other than ferritic steels are likely to satisfy these irradiation requirements. In the future attention will focus on the assessment of low-irradiation temperature effects on toughness and on the improvement of high-temperature strength for these materials. An understanding of fracture behavior in terms of irradiation temperature and fluence for ferritic steels, based on a wide series of in- and ex-reactor experiments, can build confidence in the use of these materials for fast and fusion reactor applications.

\section{CONCLUSIONS}

The radiation embrittlement of low-swelling alloys, high-nickel superalloys, austenitic steels and ferritic steels has been assessed using fracture mechanics techniques. The fracture toughness test results lead to the following observations.

- The fracture toughness of HT9 remains adequate after irradiation with fluences up to $180 \mathrm{dpa}$ at temperatures of $400{ }^{\circ} \mathrm{C}$ or higher. Irradiation temperatures have a strong effect in degrading the fracture toughness for HTg, but results show that the fracture mode of low-temperature irradiated HTg changes from cleavage fracture to dimpling rupture when the temperature is increased.

- The potential for brittle failure exists for austenitic steel 09 when irradiated to fluences above $20 \times 10^{22} \mathrm{n} / \mathrm{cm}^{2}(E>0.1 \mathrm{MeV})$. The fracture toughness of $D 9$ was found to deteriorate with increasing fluence. Samples irradiated to $23 \times 10^{22} \mathrm{n} / \mathrm{cm}^{2}$ fail by brittle fracture without plastic deformation. This embrittlement is associated with channel fracture similar to that observed in highly irradiated 316 SS. 
- Bend-test results of TEM disks show that high-nickel superalloys exhibit extremely low ductility after irradiation as a result of precipitation that occurs in narrow bands during deformation. The pre-irradiation fracture toughness of D66 is low, and the material is fractured by flow localization with the fracture surfaces characterized by channel facets.

- Subsized specimens are suitable for in-cell fracture toughness testing for irradiated materials. Use of electric potential techniques causes the irradiated 2.5 to $3.0-\mathrm{mm}$-thick specimens to display different fracture modes ranging from linear elastic behavior to stable tearing depending upon the fracture responses to irradiation. Size requirements for data validity are satisfied by all irradiated subsized specimens.

- Analysis of the fracture property values obtained by fracture mechanics techniques, together with fracture mode observation and fracture surface morphologies, provides the best method for studying the radiation embrittlement of nuclear structure materials under large neutron exposures. The results obtained in this work indicated that the service of low-swelling austenitic steels should be limited to displacement damage levels of approximately $100 \mathrm{dpa}$ and that ferritic steels are the most promising candidate materials for extended high-temperature service in fast reactors and for fusion reactor applications in very high neutron fluence environments.

\section{ACKNOWLEDGMENTS}

This paper is based work performed under U.S. Department of Energy Contract DE-AC06-87RL10930 with Westinghouse Hanford Company, a subsidiary of Westinghouse Electric Corporation. 


\section{REFERENCES}

[1] W. G. Johnston, T. Lauritzen, J. H. Rosolowski and A. M. Turakalo, An experimental survey of swelling in commercial $\mathrm{Fe}-\mathrm{Cr}-\mathrm{Ni}$ alloys bombarded with $5 \mathrm{MeV} \mathrm{Ni}$ ions. J. Nuclear Mater. 54, 24-40 (1974).

[2] B. J. Makenas, Swelling of 316 stainless steel and $D 9 \mathrm{Cladding}$ in FFTF. Radiation-Induced in Microstructure. ASTM STP 955, 146-153 (1987).

[3] D. S. Gelles, Microstructural examination of several commercial ferritic alloys irradiated to high fluence. J. Nuclear Mater. 103 and 104, 975-979 (1981).

[4] F. H. Huang and D. S. Gelles, Influence of specimen size and microstructure on the fracture toughness of a martensitic stainless stee 1. Engng Fracture Mech. 19, 1-20 (1984).

[5] F. H. Huang, Fracture toughness and tensile properties of alloy HTg in thin sections under high neutron fluence. Effects of Radiation on Materials, the 15th symposium, Nashville, Tennessee, ASTM STP 1125 (1990).

[6] Nickel and Its Alloys, section J, International Nickel Company, New York, 5-7 (1947).

[7] W. J. S. Yang, Grain boundary segregation in solution-treated Nimonic PE16. J. Nuclear Mater. 108 and 109, 339-346 (1982).

[8] R. L. Fish, J. L. Straalsund, C. W. Hunter and J. J. Holmes, Swelling and tensile property evaluations of high-fluence EBR-II thimbles. Effects of Radiation on Substructure and Mechanical Properties of Metals and Al7oys. ASTM STP 529, 149-164 (1973).

[9] F. H. Huang, The fracture characterization of highly irradiated Type 316 stainless steel. Int. J. Fracture 25, 181-193 (1983). 
[10] F. H. Huang, Fracture behavior of irradiated HT9 for structural applications. Nuclear Engng. Design 90, 13-23 (1985).

[11] W. L. Hu and D. S. Gelles, The ductile-to-brittle transition behavior of martensitic steels neutron irradiated to $26 \mathrm{dpa}$. Influence of Radiation on Material Properties. ASTM STP 956, 83-97 (1987).

[12] J. J. Laidler, J. J. Holmes and J. W. Bennett, U.S. program on reference and advanced cladding/duct materials. Radiation Effects in Bredder Reactor Structural Materials. TMS/AIME, 41-52 (1977).

[13] R. Bajaj, R. P. Shogan, C. Deflitch, R. L. Fish, M. M. Paxton and M. L. Bleiberg, Tensile properties of neutron irradiated Nimonic PE16. Effects of Radiation on Materials. ASTM STP 725, 326-351 (1980).

[14] F. H. Huang, M. L. Hamilton and G. L. Wire. Bend testing for miniature disks. Nuclear Tech. 57, 234-242 (1982).

[15] F. H. Huang, Post-irradiation fracture properties of precipitationstrengthened alloy D21. Influence of Radiation on Material Properties. ASTM STP 956, 141-150 (1987).

[16] M. L. Hamitton, F. H. Huang, W. J. S. Yang and F. A. Garner, Mechanical properties and fracture behavior of $20 \%$ cold-worked 316 stainless steel irradiated to very high neutron exposures. Influence of Radiation in Material Properties. ASTM STP 956, 245-270 (1987).

[17] A. Fissolo, R. Cauvin, J. Hugot, and V. Levy, Influence of swelling on irradiated $\mathrm{CW}$ titanium 316 embrittlement. Effects of Radiation on Materials. ASTM STP 1046, 700-713 (1990).

[18] E. A. Little, Void-swelling in irons and ferritic steels, I, mechanisms of swelling suppression. J. Nuclear Mater. 87, 11-24 (1979).

[19] A. Wolfenden, J. R. Holl and, R. G. Lott and J. A. Spitznage1, Phase 
WHC-SA-1392-FP

Rev. 1

stability in irradiated bcc materials. Phase Stability During Irradiation. TMS-AIME, 383-413 (1982). 
WHC-SA-1392-FP

Rev. 1

TABLE 1. CHEMICAL COMPOSITIONS.

\begin{tabular}{|c|c|c|c|c|c|}
\hline Element & $\underline{D 66}$ & $\begin{array}{l}\text { HT9 } \\
\text { (Heat No. 91353) } \\
\end{array}$ & $\begin{array}{c}\text { HT9 } \\
(84425) \\
\end{array}$ & $\begin{array}{r}09 \\
(N 562) \\
\end{array}$ & $\begin{array}{r}D 9 \\
(2966) \\
\end{array}$ \\
\hline $\mathrm{Cr}$ & 12.0 & 11.97 & 11.87 & 13.5 & 14.06 \\
\hline $\mathrm{Ni}$ & 45.0 & 0.57 & 0.53 & 16.07 & 15.60 \\
\hline Mo & 3.0 & 1.03 & 1.02 & 1.5 & 1.45 \\
\hline v & - & 0.33 & 0.30 & $<0.2$ & - \\
\hline$S i$ & 0.5 & 0.22 & 0.27 & 0.97 & 1.05 \\
\hline$M n$ & - & 0.49 & 0.58 & 1.7 & 2.3 \\
\hline C & 0.03 & 0.21 & 0.2 & 0.048 & 0.043 \\
\hline AT & 2.5 & 0.023 & 0.002 & $<0.05$ & 0.05 \\
\hline $\mathrm{Ti}$ & 2.5 & 0.002 & $<0.01$ & 0.2 & 0.25 \\
\hline P & - & 0.08 & 0.003 & $<0.02$ & 0.011 \\
\hline$S$ & - & 0.03 & 0.004 & $<0.01$ & 0.001 \\
\hline Co & - & 0.01 & 0.011 & $<0.05$ & 0.04 \\
\hline $\mathrm{Cu}$ & - & 0.074 & 0.013 & $<0.04$ & 0.03 \\
\hline B & 0.005 & 0.001 & 0.001 & $<0.001$ & $<0.001$ \\
\hline$W$ & - & 0.52 & 0.55 & - & - \\
\hline As & - & $<0.005$ & $<0.005$ & $<0.03$ & $<0.01$ \\
\hline$N$ & - & 0.004 & 0.0017 & $<0.01$ & 0.007 \\
\hline $\mathrm{Cb}$ & - & 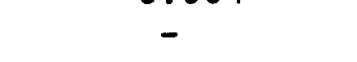 & - & $<0.05$ & 0.01 \\
\hline $\mathrm{Ta}$ & - & - & - & $<0.02$ & $<0.01$ \\
\hline $\mathrm{Zr}$ & 0.05 & - & - & - & - \\
\hline$=$ & $\mathrm{Ba}$. & Bal. & Bal. & Bal. & Bal. \\
\hline
\end{tabular}


Rev. 1

TABLE 2. FRACTURE TOUGHNESS RESULTS FOR LOW-SWELLING ALLOYS.

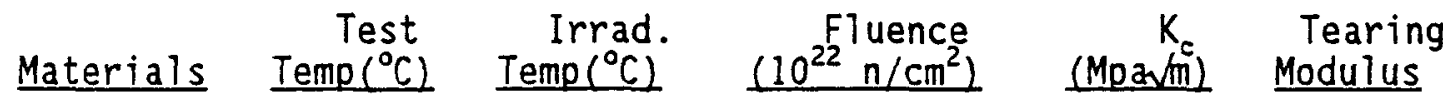

$\begin{array}{crrrrr}\text { D66 } & 25 & --- & 0 & 72.3 & 4 \\ & 232 & --- & 0 & 74.2 & 4 \\ \text { D9 Duct } & 205 & 457 & 9 & 93.9 & 66 \\ & 410 & 455 & 10 & 70.8 & 18 \\ & 410 & 390 & 22.8 & <30.1 & 0 \\ & --- & 423 & 21.3 & \star & * \\ \text { D9(2966) } & -- & 430 & 20.0 & & -\cdots \\ & 32 & 410 & 17.5 & 79.9 & 18 \\ & 205 & 410 & 20.9 & 61.4 & 4 \\ \text { HT9(91353) } & 410 & 410 & 20.9 & 58.0 & -\cdots \\ & 32 & 550 & 13 & 129.5 & 211 \\ & 205 & 550 & 13 & 101.6 & 146 \\ & 25 & 405 & 17.5 & 110.0 & 79 \\ & 205 & 405 & 17.5 & 108.9 & 80 \\ & 30 & 410 & 38.5 & 103.0 & 78 \\ & 205 & 410 & 38.5 & 96.4 & 70 \\ \text { HT9(84425) } & 410 & 410 & 38.5 & 93.7 & 55 \\ & 205 & 550 & 14 & 122.1 & 105 \\ & 410 & 550 & 14 & 97.4 & 137 \\ & 30 & 410 & 32.9 & 121.8 & 58 \\ & 205 & 410 & 32.9 & 110.6 & 79 \\ & 410 & 410 & 32.9 & 100.3 & 39\end{array}$

* Failed at 13.9 MPavm During Fatigue Precracking

** Failed at 12.4 MPavm During Fatigue Precracking 
TABLE 3. DISK BEND-TEST RESULTS.

\begin{tabular}{|c|c|c|c|c|c|}
\hline ALLOY & COMPOSITION & $\begin{array}{l}\text { HEAT } \\
\text { CODE }\end{array}$ & $\begin{array}{l}\text { BEND DUCTII } \\
\text { T.T. }=I . T \\
\text { I.T. }=500 \\
\end{array}$ & $\begin{array}{l}\text { ITY }(\%) \\
+110 \\
550\end{array}$ & $\begin{array}{l}{ }^{\circ} \mathrm{C} \\
600 \\
\end{array}$ \\
\hline Nimonic PEl6 & $\begin{array}{l}\mathrm{Fe}-34.0 \mathrm{Ni}-43.5 \mathrm{Cr}-16.5 \\
\mathrm{Mo}-3.3 \mathrm{Mn}-0.1 \mathrm{Ti}-1.2 \mathrm{Al}-1.2 \\
\mathrm{Si}-0.2 \mathrm{Nb}-0.05 \mathrm{C}-0.05 \mathrm{~B}-0.01\end{array}$ & $1 C$ & 0.40 & 0.44 & 0.20 \\
\hline Inconel 706 & $\begin{array}{l}\mathrm{Fe}-37.0 \mathrm{Ni}-41.5 \mathrm{Cr}-16.0 \\
\mathrm{Mo}-0.1 \mathrm{Si}-0.2 \mathrm{Mn}-0.2 \mathrm{Ti}-1.75 \\
\mathrm{Al}-0.2 \mathrm{Nb}-2.9 \mathrm{C}-0.03 \quad \mathrm{~B}-0.001\end{array}$ & $7 C$ & - & 0.20 & - \\
\hline Inconel 718 & $\begin{array}{l}\mathrm{Fe}-18.6 \mathrm{Cr}-19.0 \mathrm{Ni}-52.5 \mathrm{Mo}-3.0 \\
\mathrm{Nb}-5.1 \mathrm{Ti}-0.9 \mathrm{Al}-0.5 \mathrm{Si}-0.1 \\
\mathrm{Mn}-0.18 \mathrm{C}-0.04\end{array}$ & $7 \mathrm{~J}$ & - & 0.44 & - \\
\hline Incoloy 901 & $\begin{array}{l}\mathrm{Fe}-36 \mathrm{Ni}-42.5 \mathrm{Cr}-12.5 \mathrm{Mn}-0.1 \\
\mathrm{Mo}-5.7 \mathrm{Ti}-2.8 \mathrm{Al}-0.2 \mathrm{C}-0.05 \\
\mathrm{Si}-0.1 \mathrm{~B}-0.015\end{array}$ & $7 p$ & - & 0.14 & - \\
\hline A286 & $\begin{array}{l}\mathrm{Fe}-53 \mathrm{Cr}-15 \mathrm{Ni}-26 \mathrm{Mo}-1.25 \\
\mathrm{Ti}-2.15 \mathrm{Al}-0.2 \mathrm{Si}-0.4 \mathrm{Mn}-1.4 \\
\mathrm{~V}-0.3 \mathrm{C}-0.05\end{array}$ & $7 R$ & - & 0.78 & - \\
\hline$M 813$ & $\begin{array}{l}\mathrm{Fe}-39 \mathrm{Cr}-18 \mathrm{Ni}-35 \mathrm{Mo}-4 \\
\mathrm{Ti}-2.25 \mathrm{Al}-1.4 \mathrm{C}-0.08\end{array}$ & $7 \mathrm{~K}$ & - & 0.04 & - \\
\hline
\end{tabular}


TABLE 3. DISK BEND TEST RESULTS (Cont.)

\begin{tabular}{|c|c|c|c|c|c|}
\hline ALLOY & COMPOS ITION & $\begin{array}{l}\text { HEAT } \\
\text { COOE }\end{array}$ & $\begin{array}{l}\text { BEND DUCT } \\
\text { T.T. }=I . \\
\text { I.T. }=500\end{array}$ & $\begin{array}{l}\text { ITY }(\%) \\
+110 \\
550\end{array}$ & $\begin{array}{l}{ }^{\circ} \mathrm{C} \\
600 \\
\end{array}$ \\
\hline D42 & $\begin{array}{l}\mathrm{Fe}-19 \mathrm{Cr}-15 \mathrm{Ni}-60 \mathrm{Mo}-5 \\
\mathrm{Al}-1.5 \mathrm{Ti}-1.5 \mathrm{Nb}-1.5 \mathrm{Si}-0.5 \\
\mathrm{~B}-0.01 \mathrm{Zr}-0.03 \mathrm{C}-0.03\end{array}$ & $B P$ & - & 0.26 & - \\
\hline D66 & $\begin{array}{l}\mathrm{Fe}-34 \mathrm{Ni}-45 \mathrm{Cr}-12 \mathrm{Mo}-3 \\
\mathrm{Ti}-2.5 \mathrm{Al}-2.5 \mathrm{Si}-0.5 \mathrm{Zr}-0.05 \\
\mathrm{~B}-0.005 \mathrm{C}-0.03\end{array}$ & $\begin{array}{l}\text { LJ } \\
\text { LN }\end{array}$ & $\begin{array}{c}0.40 \\
-\end{array}$ & $\begin{array}{c}0.60 \\
-\end{array}$ & $\overline{0}$ \\
\hline 021 & $\begin{array}{l}\mathrm{Fe}-58.5 \mathrm{Ni}-25 \mathrm{Cr}-8.4 \mathrm{M0}-1.0 \\
\mathrm{Si}-1.0 \mathrm{Mn}-1.0 \mathrm{Ti}-3.3 \mathrm{Al}-1.7 \\
\mathrm{Nb}-0.05 \mathrm{C}-0.04 \mathrm{~B}-0.001\end{array}$ & $\begin{array}{l}\text { L0 } \\
\text { L3 }\end{array}$ & $\begin{array}{c}>0.50 \\
-\end{array}$ & $\begin{array}{c}0.61 \\
-\end{array}$ & $\begin{array}{c}0.81 \\
0\end{array}$ \\
\hline D68 & $\begin{array}{l}\mathrm{Fe}-36 \mathrm{Ni}-45 \mathrm{Cr}-12 \mathrm{Mo}-0.1 \\
\mathrm{Si}-0.4 \mathrm{Mn}-0.3 \mathrm{Ti}-1.8 \mathrm{Al}-0.4 \\
\mathrm{Mb}-3.6 \mathrm{C}-0.03 \mathrm{~B}-0.005\end{array}$ & $\begin{array}{l}\text { LV } \\
N C\end{array}$ & - & - & $\begin{array}{c}0 \\
0.16\end{array}$ \\
\hline
\end{tabular}




$$
\begin{gathered}
\text { WHC-SA-1392-FP } \\
\text { Rev. } 1
\end{gathered}
$$

TABLE 4. SWELLING DATA FOR 20\% COLD WORKED 316 STAINLESS STEEL,

\begin{tabular}{|c|c|c|c|c|c|}
\hline Specumen & A110y & Heat No. & $\begin{array}{l}\text { Irradiation } \\
\text { Temp. }\left({ }^{\circ} \mathrm{C}\right)\end{array}$ & $\begin{array}{r}\text { Fluence } \\
\left(10^{22} \mathrm{n} / \mathrm{cm}^{2}\right) \\
\end{array}$ & $\Delta V / V(\%)$ \\
\hline $\begin{array}{l}\mathrm{ABO} 1 \\
\mathrm{ABO} 4\end{array}$ & $\begin{array}{ll}316 & \mathrm{SS} \\
316 & \mathrm{SS}\end{array}$ & $\begin{array}{l}93591 \\
93591\end{array}$ & $\begin{array}{l}410 \\
410\end{array}$ & $\begin{array}{l}37.2 \\
37.2\end{array}$ & $\begin{array}{l}17.7 \\
23.2\end{array}$ \\
\hline $\begin{array}{l}\text { EFO1 } \\
\text { EF02 }\end{array}$ & $\begin{array}{l}09 \\
09\end{array}$ & $\begin{array}{l}83508 \\
83508\end{array}$ & $\begin{array}{l}410 \\
410\end{array}$ & $\begin{array}{l}36.9 \\
36.9\end{array}$ & $\begin{array}{l}31.4 \\
29.8\end{array}$ \\
\hline $\begin{array}{l}\text { HK21 } \\
\text { HK22 } \\
\text { AN18 } \\
\text { AN20 }\end{array}$ & $\begin{array}{l}\text { HT9 } \\
\text { HT9 } \\
\text { HT9 } \\
\text { HT9 }\end{array}$ & $\begin{array}{l}91353 \\
91353 \\
84425 \\
84425\end{array}$ & $\begin{array}{l}550 \\
550 \\
410 \\
410\end{array}$ & $\begin{array}{l}13 \\
13 \\
32.9 \\
32.9\end{array}$ & $\begin{array}{l}0.03 \\
0.02 \\
0.22 \\
0.31\end{array}$ \\
\hline
\end{tabular}
D9 AND HT9 
WHC-SA-1392-FP

Rev. 1

Figure 1. Load and Electric Potential Records for Unstable Fracture Behavior.

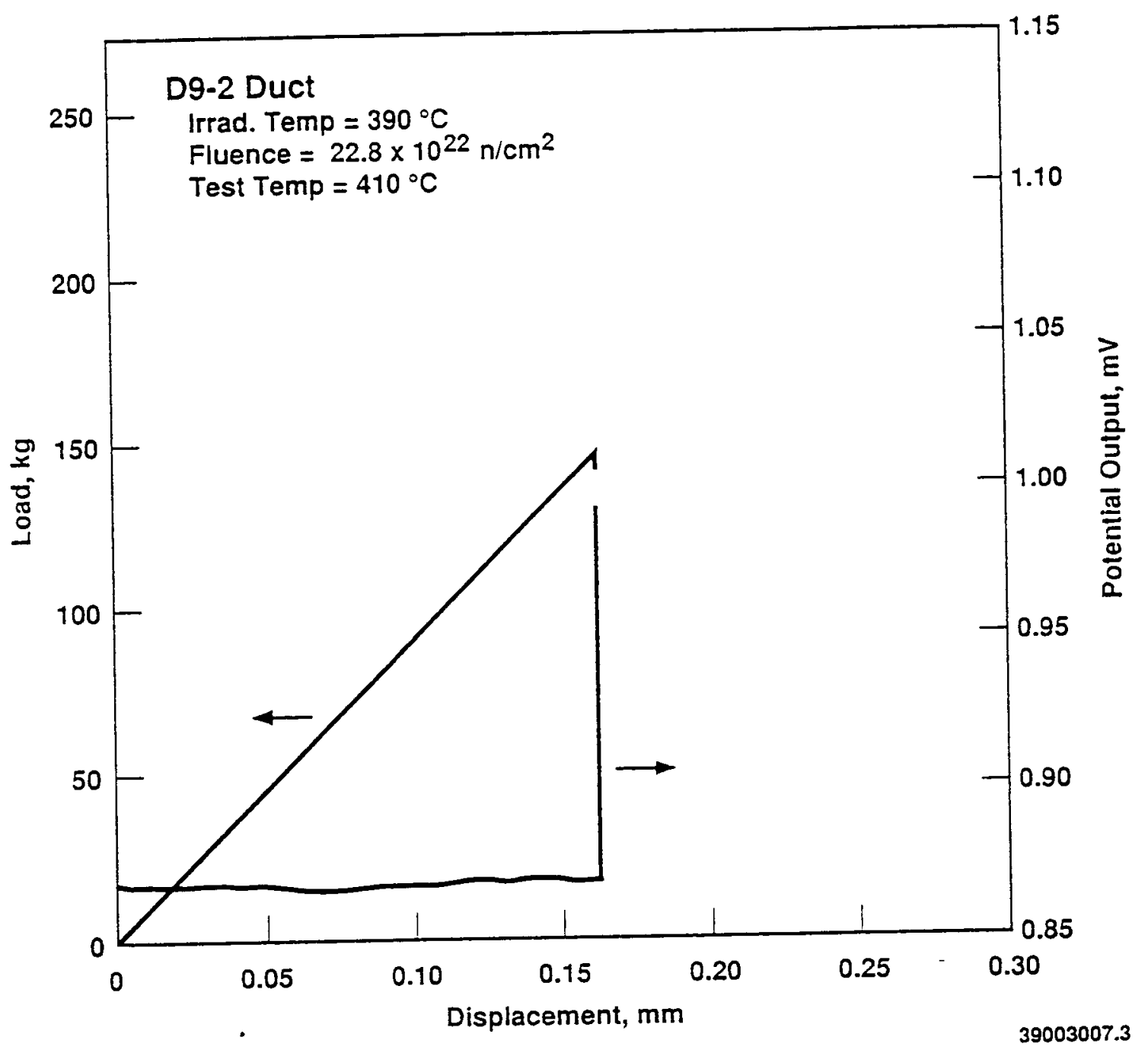


WHC-SA-1392-FP

Rev. 1

Figure 2. Load and Electric Potential Records for Stable/Unstable Fracture Behavior.

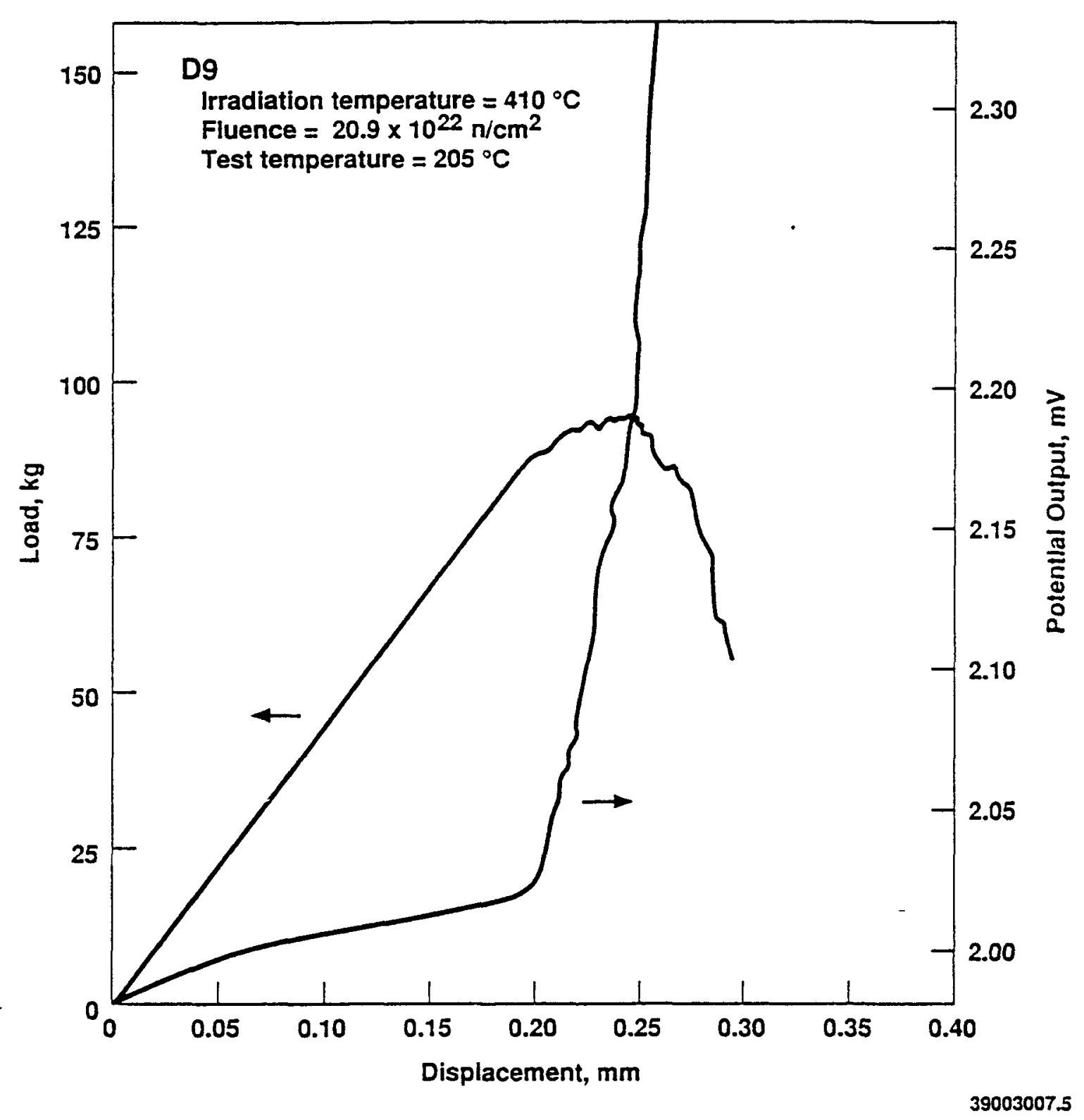


WHC-SA-1392-FP

Rev. 1

Figure 3. Load and Electric Potential Records for Stable Tearing Fracture Behavior.

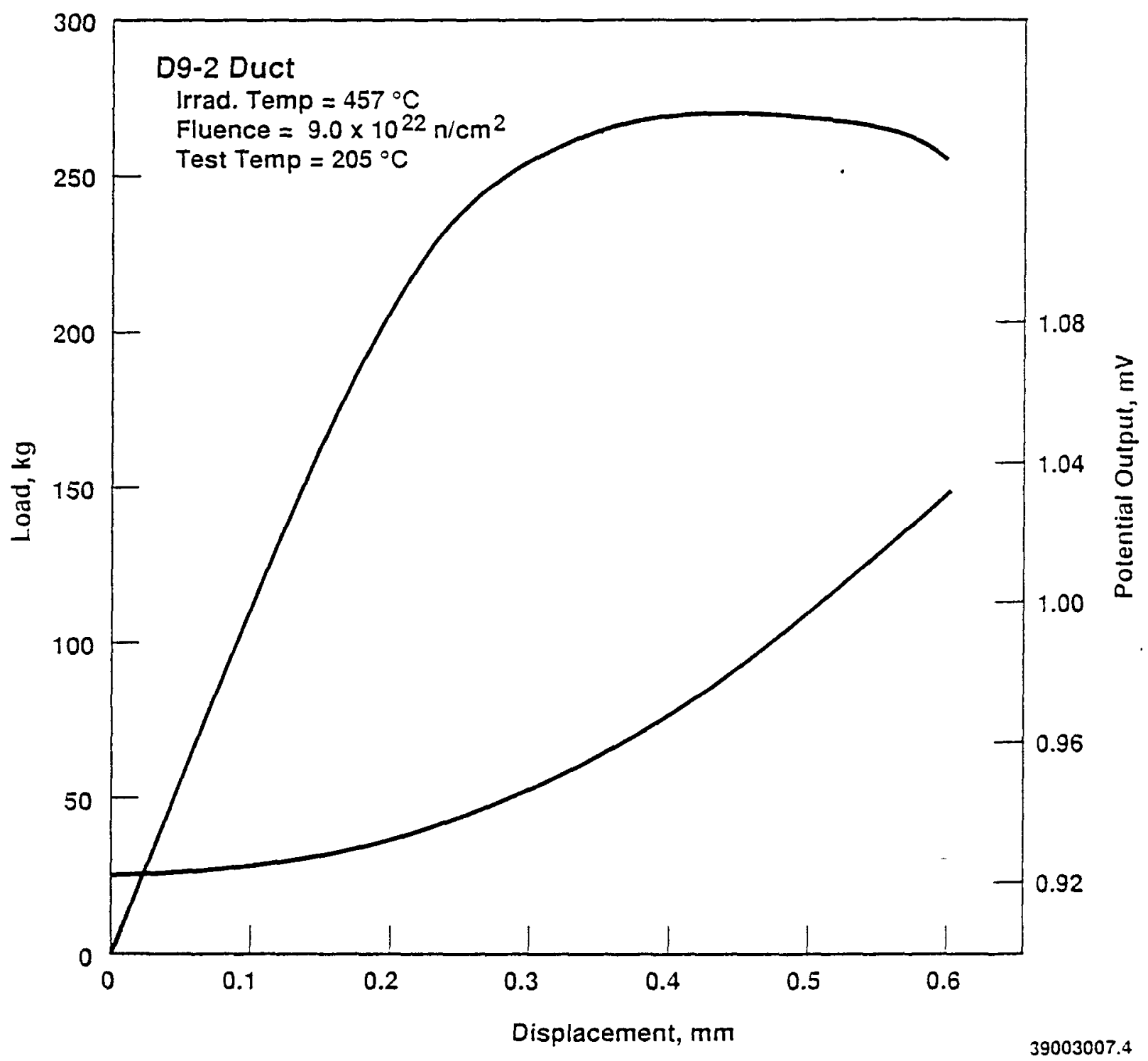


WHC-SA-1392-FP

Rev. 1

Figure 4. Load and Electric Potential Records for 066 Tested at $25^{\circ} \mathrm{C}$.

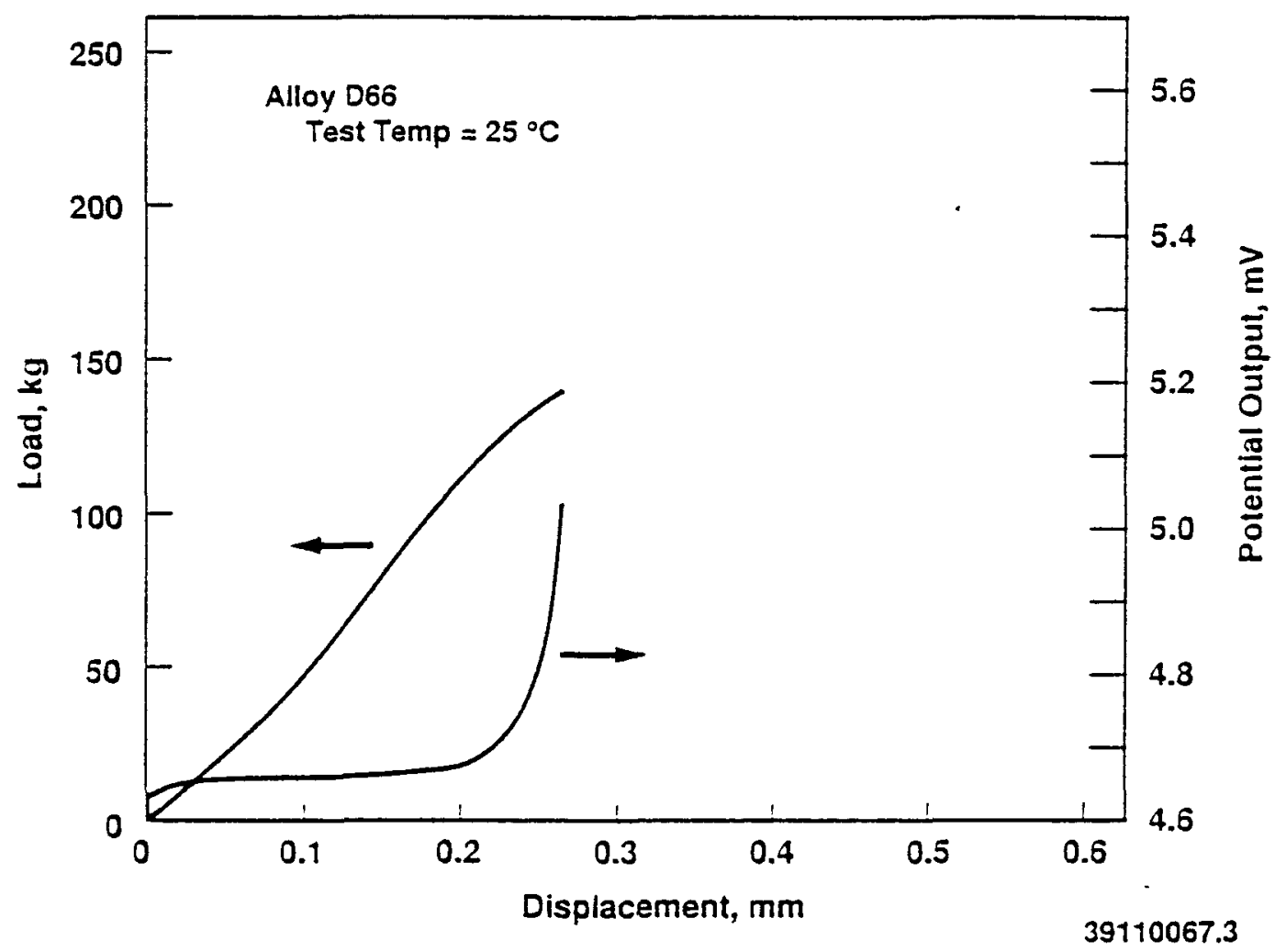


WHC-SA-1392-FP

Rev. 1 .

Figure 5. Temperature Dependence of Fracture Toughness for 021 and 066 .

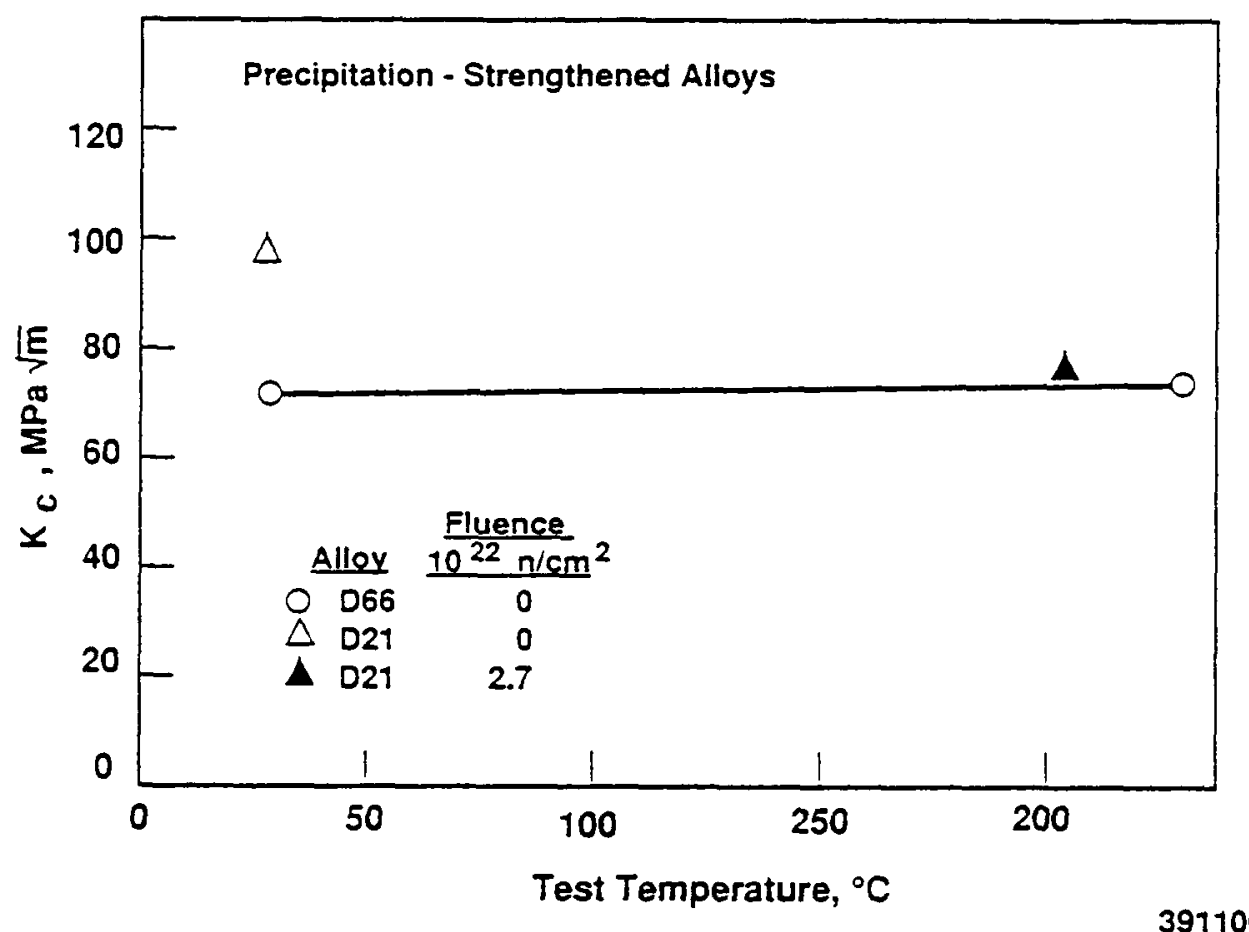

39710067.5 
WHC-SA-1392-FP

Rev. 1

Figure 6. Temperature Dependence of Tearing Modulus for D21, D66 and D9.

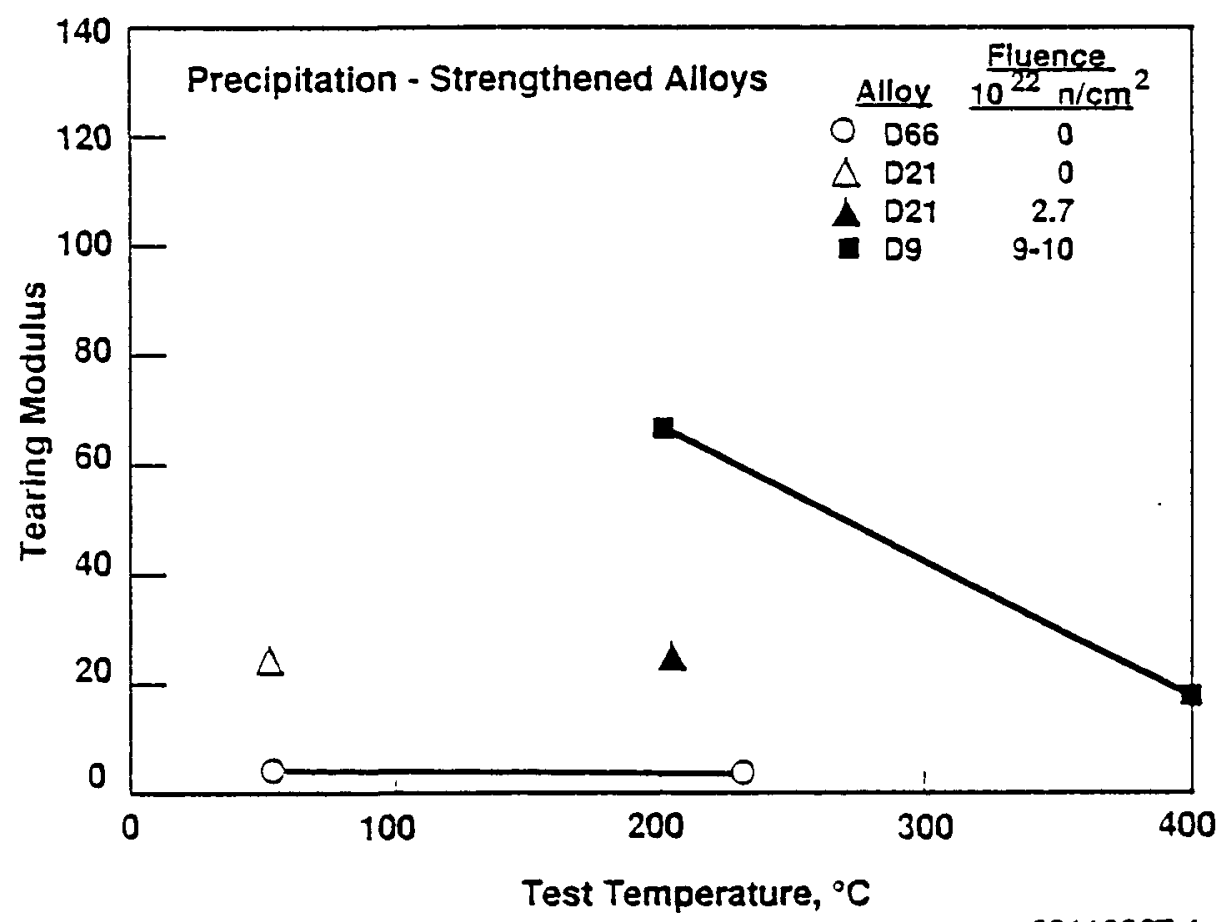




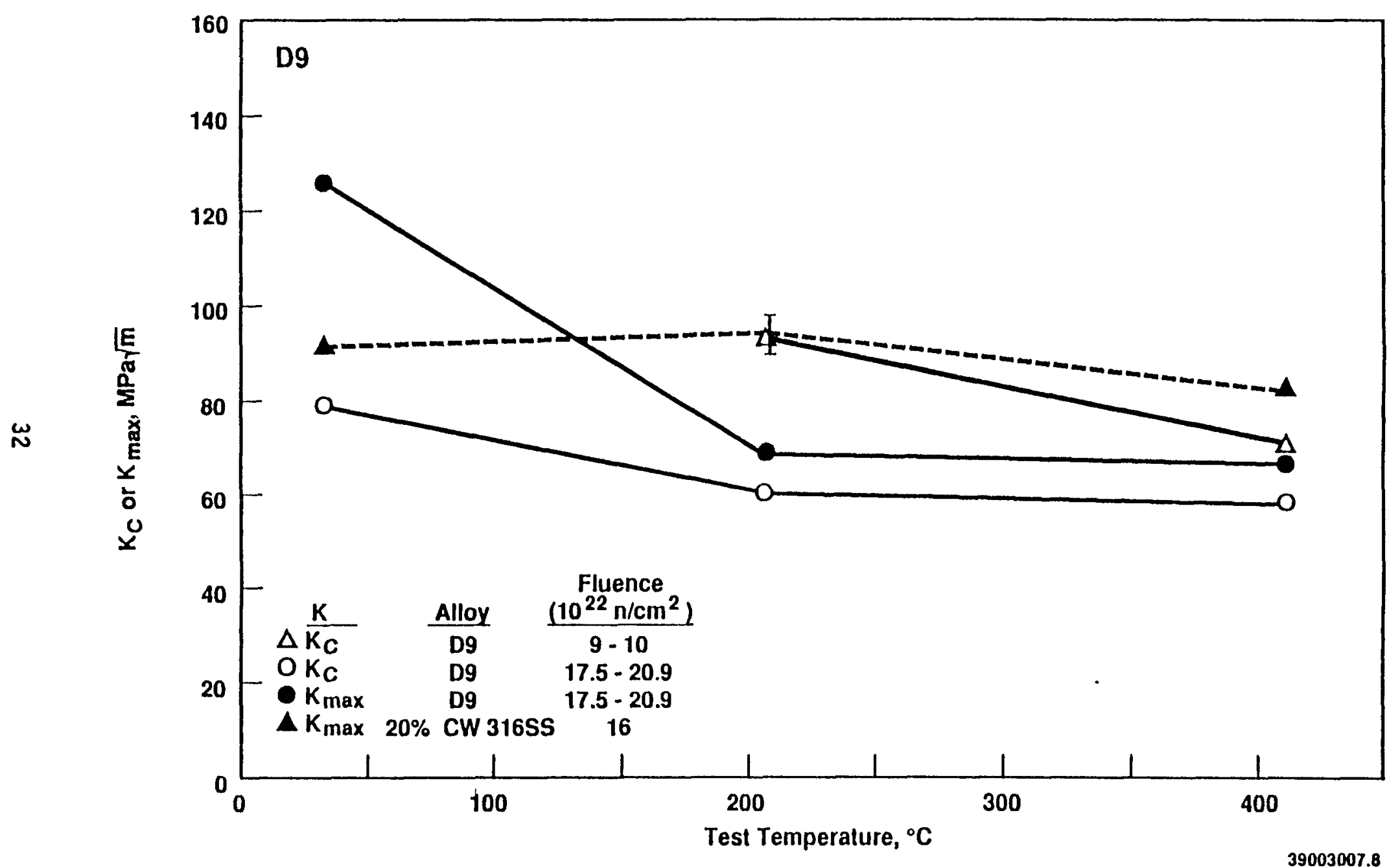


WHC-SA-1392-FP

Rev. 1

Figure 8. Load and Electric Potential Records for HT9 Irradiated to $38.5 \times 10^{22} \mathrm{n} / \mathrm{cm}^{2}$.

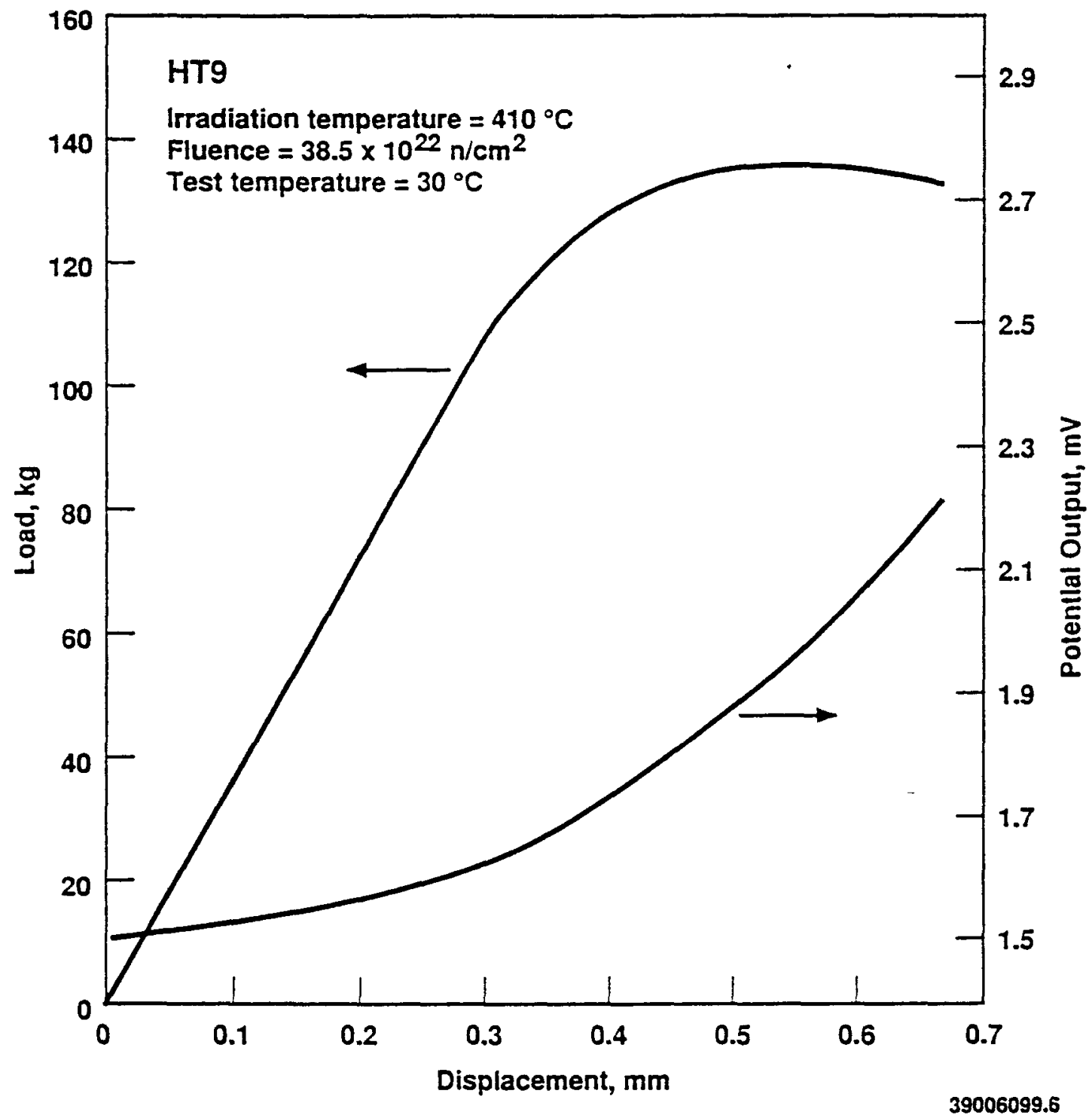




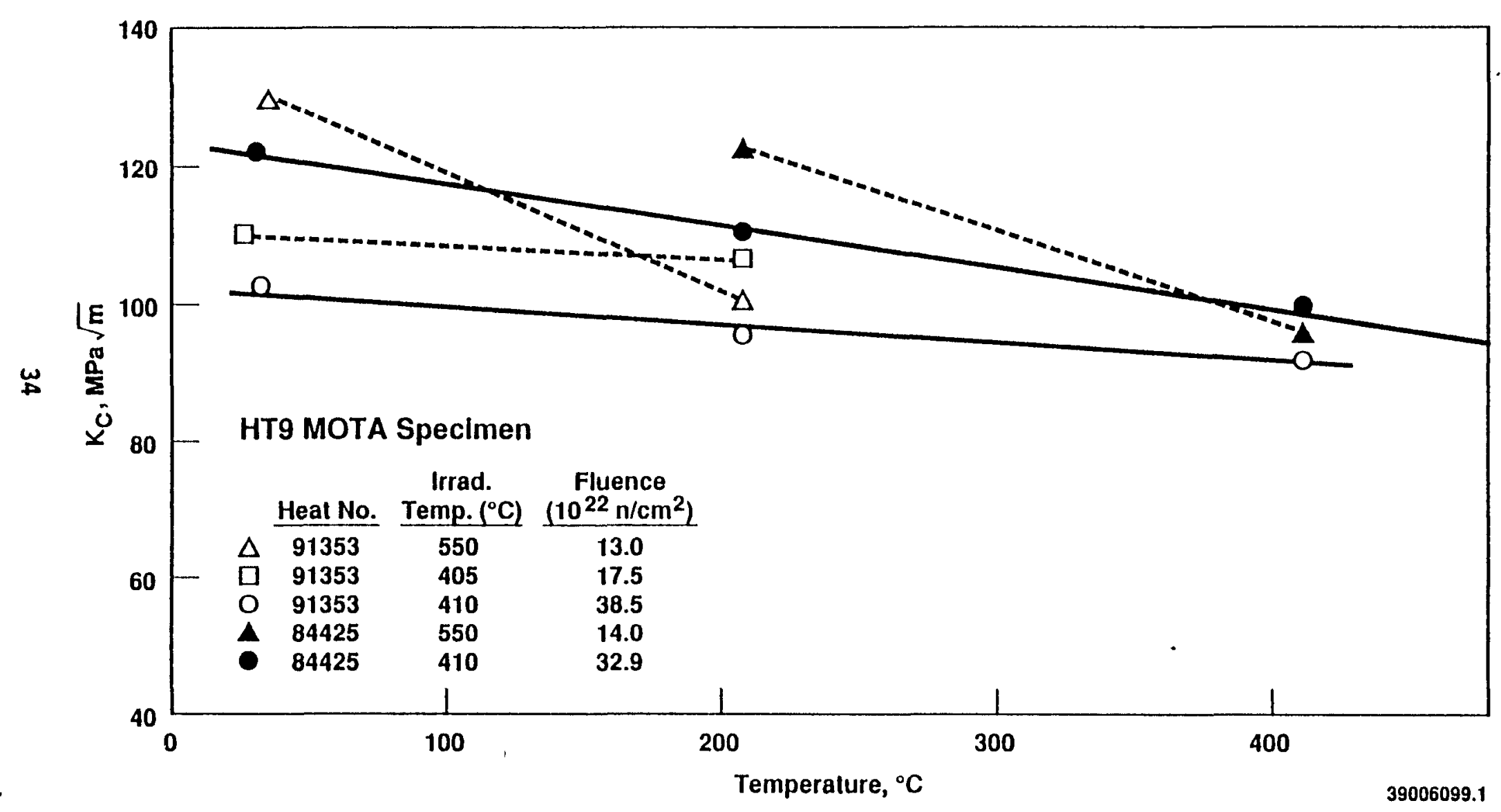


WHC-SA-1392-FP

Rev. 1

Figure 10. Temperature Dependence of Tearing Modulus for Irradiated HT9.

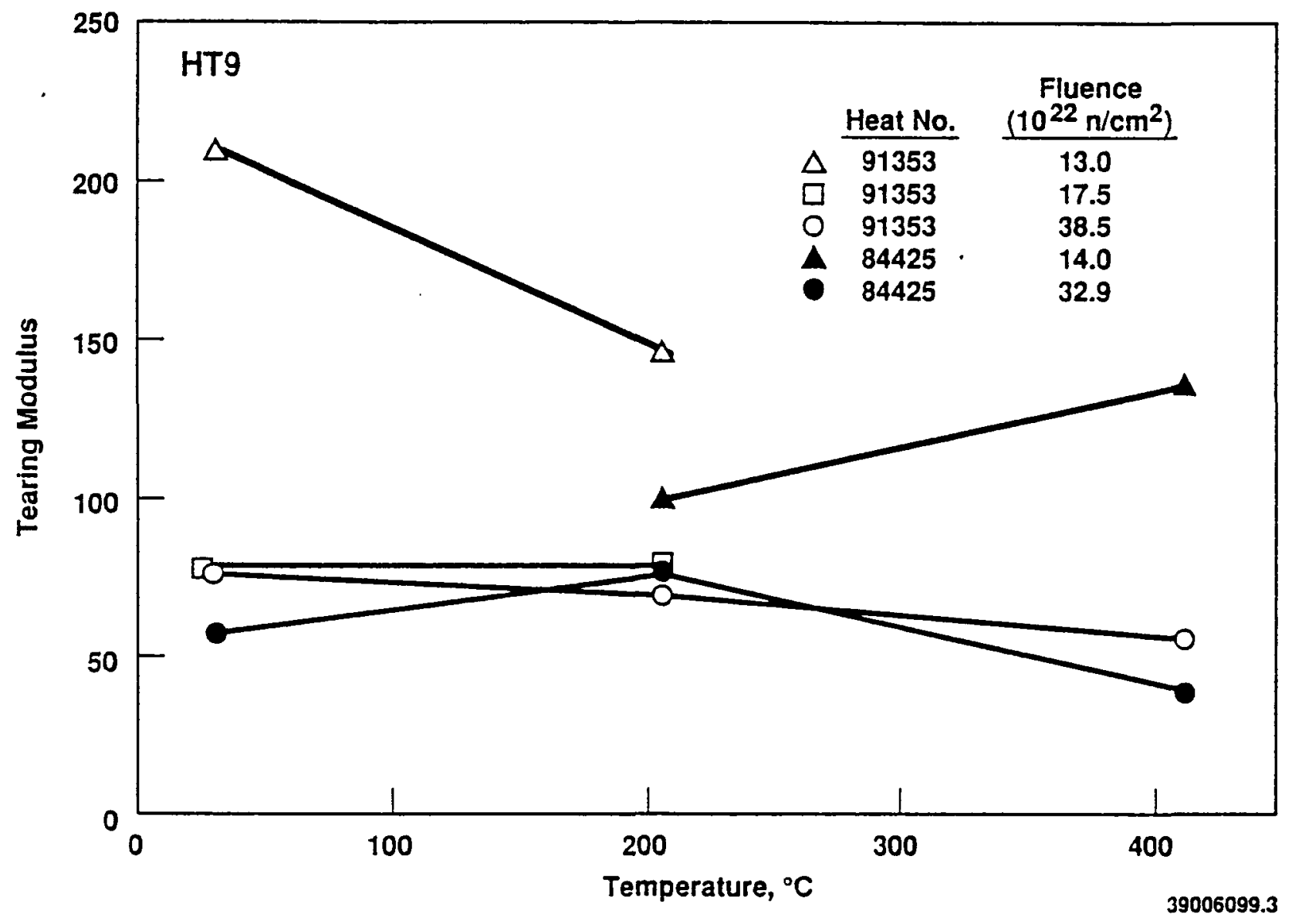


Figure 11. Scanning Electron Microscope Fractography for D66 Tested at $232{ }^{\circ} \mathrm{C}$ (a) $200 \times$ Magnification (b) 1000x Magnification.

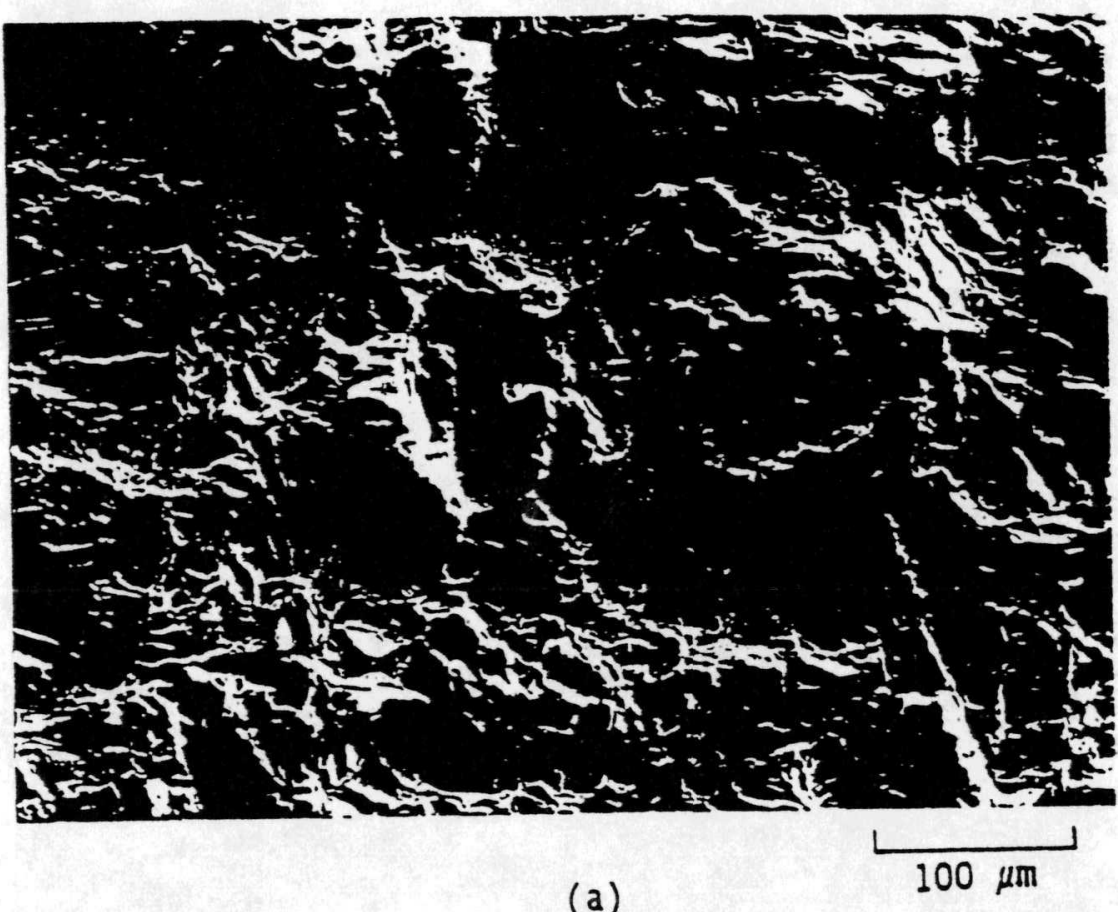

(a)

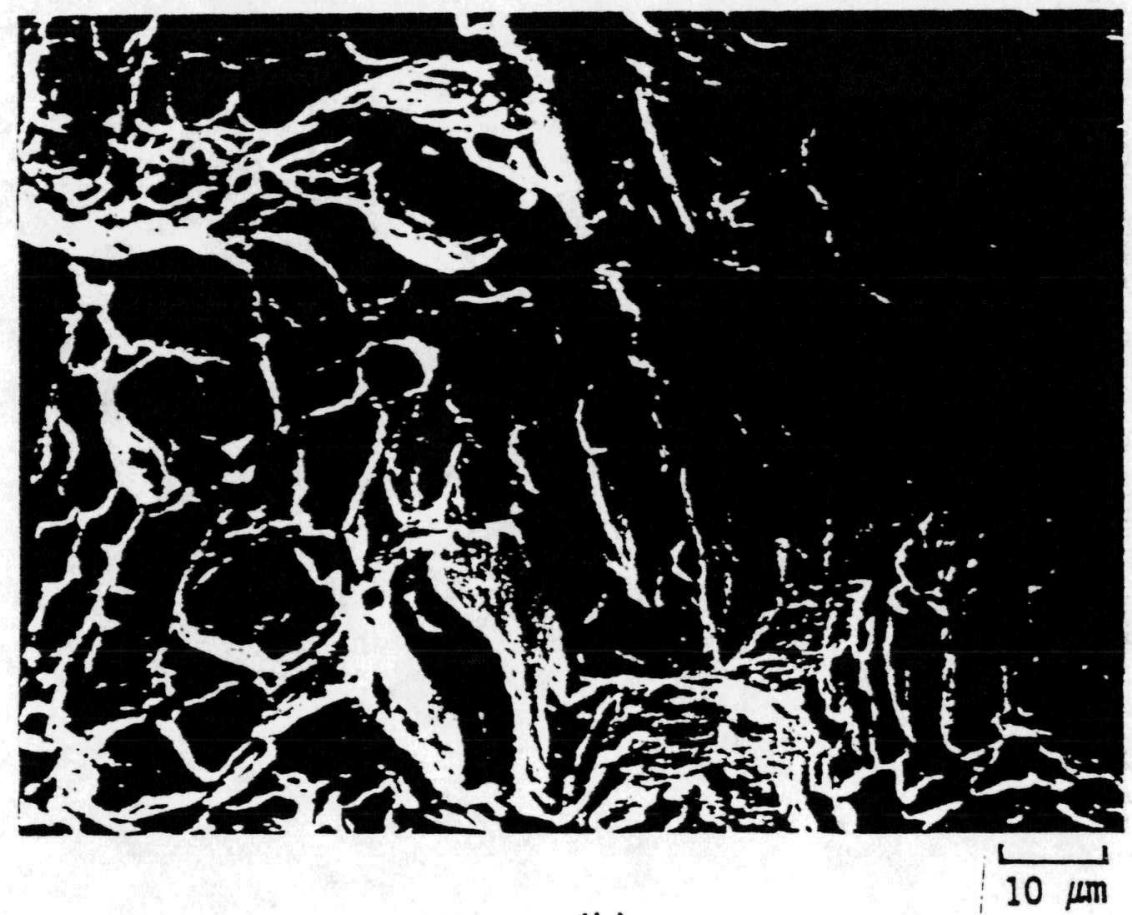

(b) 
Figure 12. Scanning Electron Microscope Fractography for HTg (a) Irradiated at $360^{\circ} \mathrm{C}$ and Tested at $205^{\circ} \mathrm{C}$ (b) Irradiated at $360^{\circ} \mathrm{C}$ and Tested at $32^{\circ} \mathrm{C}$. $1000 \times$ Magnification.
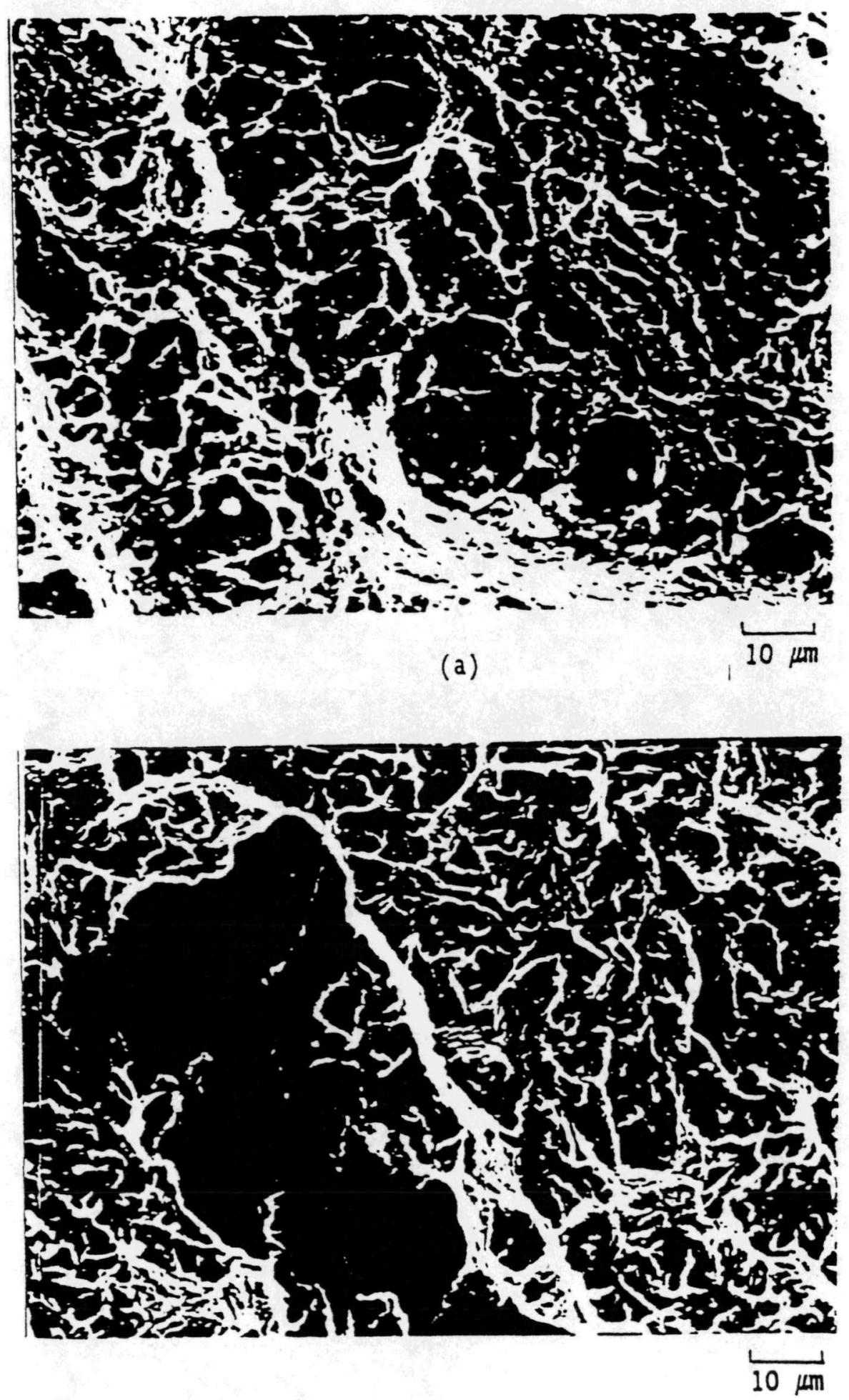

(b) 
WHC-SA-1392-FP

Rev. 1

Figure 13. Fluence Dependence of $K_{c}$ or $K_{\max }$ for Irradiated 09.

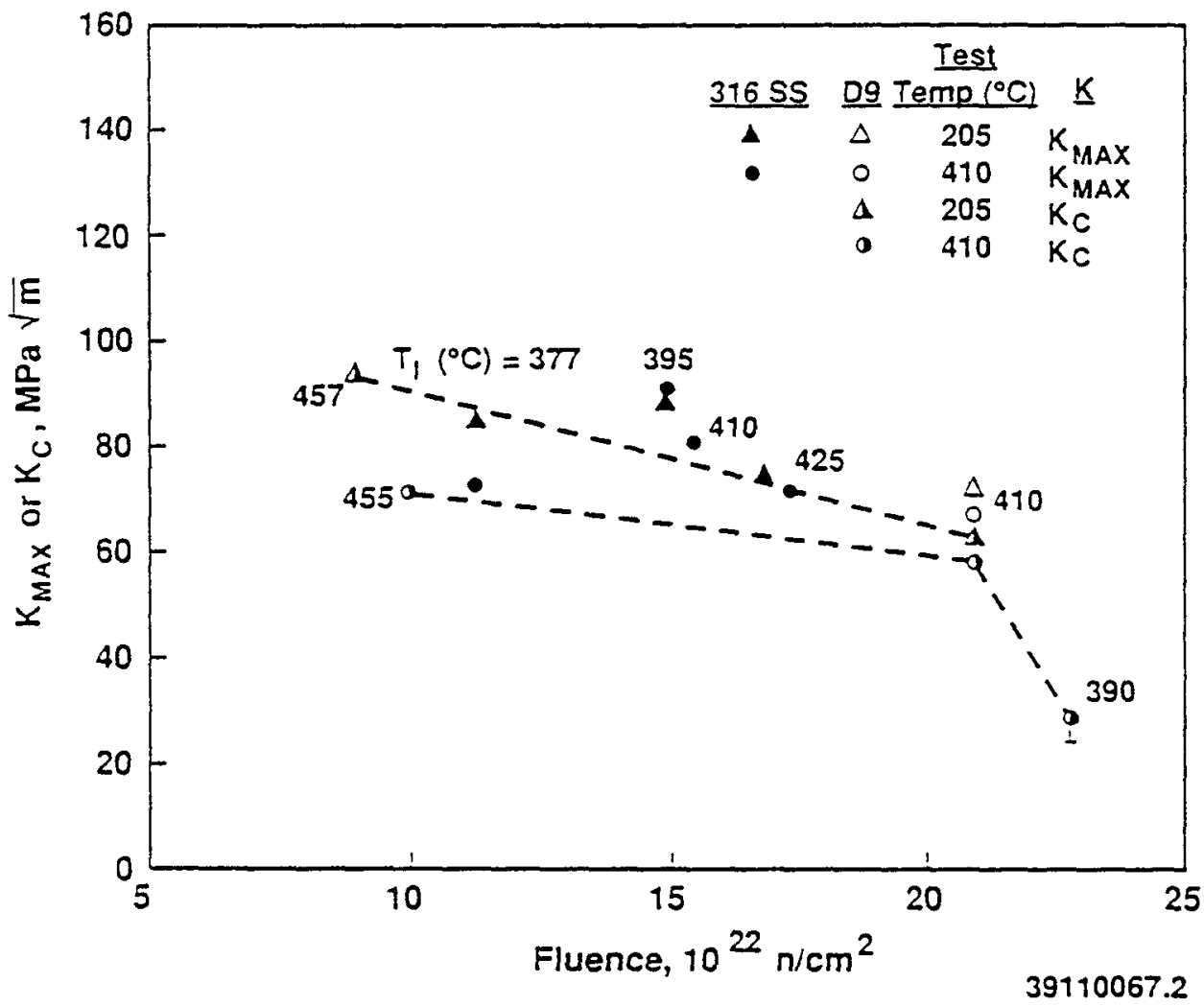


WHC-SA-1392-FP

Rev. 1

Figure 14. Fluence Dependence of $K_{c}$ for Irradiated HT9.

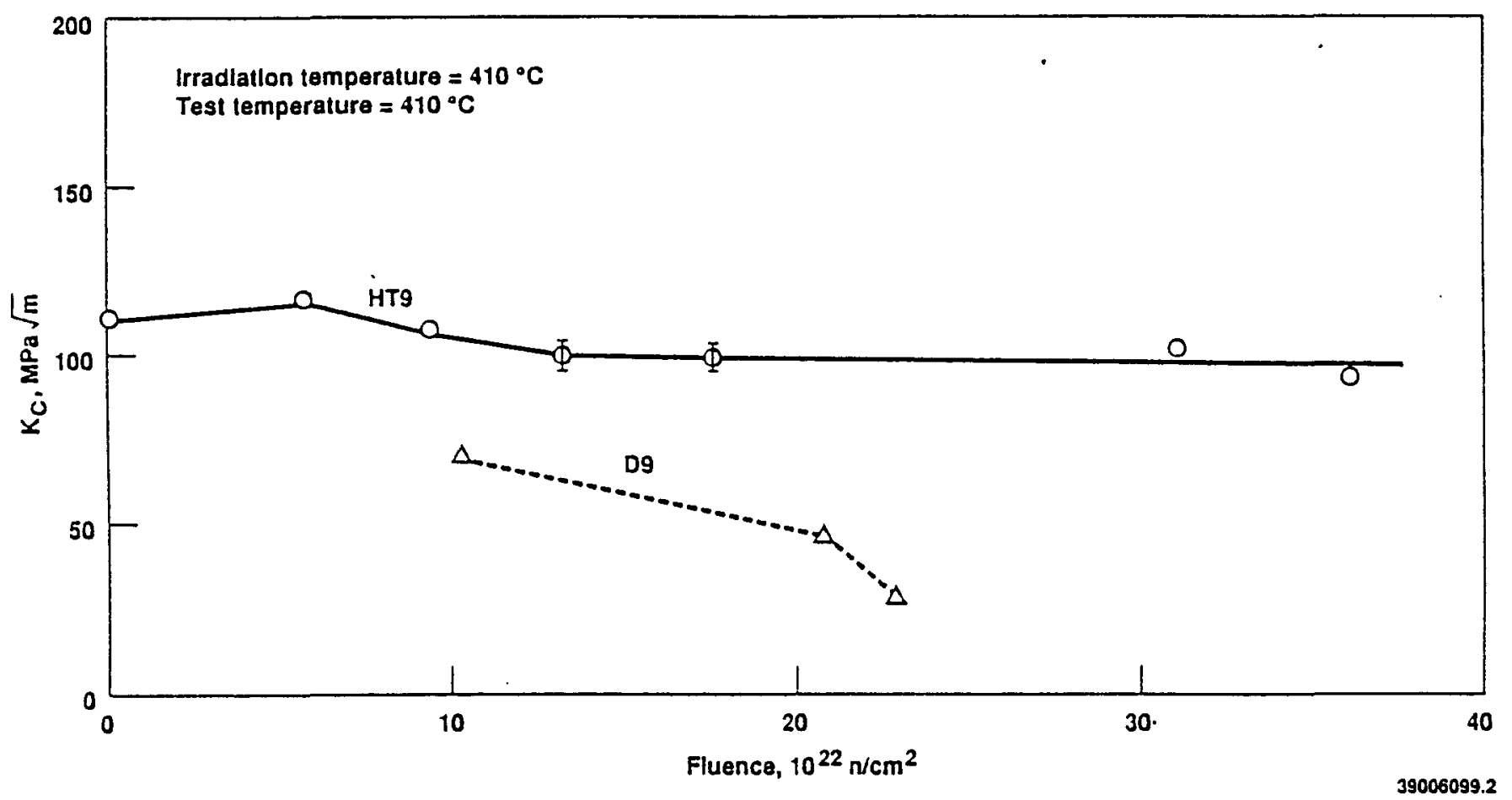


WHC-SA-1392-FP

Rev. 1

Figure 15. Fluence Dependence of Tearing Modulus for Irradiated HT9.

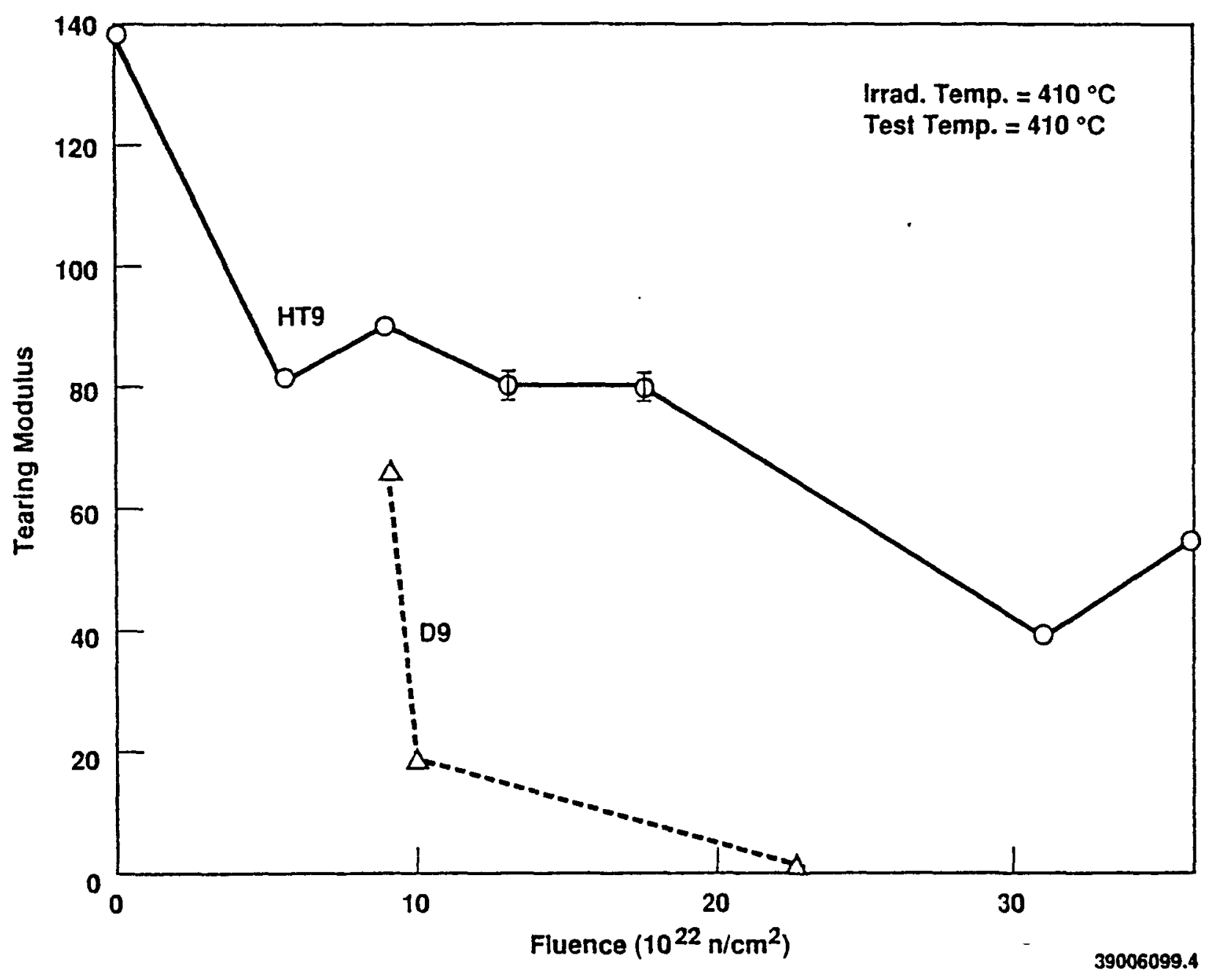




\section{WHC-SA-1392-FP \\ Rev. 1 \\ DISTRIBUTION}

Number of copies

\section{ONSITE}

10

Westinghouse Hanford Company

$\begin{array}{ll}\text { W. F. Brehm } & H 5-67 \\ \text { F. H. Huang (2) } & H 5-67 \\ \text { Information Release } & \\ \text { Administration (2) } & \\ \text { Document Processing and } & L 8-07 \\ \text { Distribution } & \mathrm{L}\end{array}$

